\title{
Article
}

\section{Socially responsible sourcing: reviewing the literature and its use of theory}

Bell, Marta, Hendry, Linda C., Huq, Fahian Anisul and Stevenson, Mark

Available at http://clok.uclan.ac.uk/28022/

Bell, Marta, Hendry, Linda C., Huq, Fahian Anisul and Stevenson, Mark (2015) Socially responsible sourcing: reviewing the literature and its use of theory. International Journal of Operations \& Production Management, 35 (1). pp. 60 109. ISSN 0144-3577

It is advisable to refer to the publisher's version if you intend to cite from the work. http://dx.doi.org/10.1108/IJOPM-07-2013-0355

For more information about UCLan's research in this area go to http://www.uclan.ac.uk/researchgroups/ and search for <name of research Group>.

For information about Research generally at UCLan please go to http://www.uclan.ac.uk/research/

All outputs in CLoK are protected by Intellectual Property Rights law, including Copyright law. Copyright, IPR and Moral Rights for the works on this site are retained by the individual authors and/or other copyright owners. Terms and conditions for use of this material are defined in the policies page. 


\section{Socially Responsible Sourcing: \\ Reviewing the Literature and its Use of Theory}

Name: $\quad$ Dr Marta Zorzini

Affiliation: Department of Management Science

Lancaster University Management School

Lancaster University

Lancaster

U.K.

Name: $\quad$ Prof. Linda C. Hendry

Affiliation: Department of Management Science

Lancaster University Management School

Lancaster University

Lancaster

U.K.

Name: $\quad$ Fahian Anisul Huq

Afiliation: Department of Management Science

Lancaster University Management School

Lancaster University

Lancaster

U.K.

Name: $\quad$ Dr Mark Stevenson

Afiliation: Department of Management Science

Lancaster University Management School

Lancaster University

Lancaster

U.K. 


\title{
Socially Responsible Sourcing: \\ Reviewing the Literature and its Use of Theory
}

\begin{abstract}
Purpose: To determine the state-of-the-art in Socially Responsible Sourcing (SRS) research, leading to an agenda for further work; and, to evaluate the use of theory in this context. SRS is defined as the upstream social issues within the sustainability literature, where social issues include human rights, community development and ethical issues but exclude environmental concerns.
\end{abstract}

Design/methodology/approach: A systematic literature review of 157 papers that include SRS published in ABS listed journals. The papers have been analysed according to their research content, with a particular focus on the use of pre-existing theories.

Findings: Key findings for researchers and managers alike include an analytical discussion of strategies developed to date to embed SRS in an organisation; and key research gaps include a particular need to consider the supplier perspective in developing countries. In terms of the use of theory, a typology is proposed, which (in ascending order of effectiveness) is as follows: theory dressing, theory matching, theory suggesting/explaining and theory expansion.

Research limitations/implications: The review is limited to papers published in the ABS list; and the analysis of the use of theory is limited to the SRS literature. The findings suggest that insightful papers can be written without any use of theory but that as a field develops, a greater depth of application of theory is needed to aid understanding.

Originality/value: This is the only review that focuses exclusively on SRS, excluding environmental issues, thus allowing for a greater depth of discussion on social issues; and is unique in its detailed critical analysis of the use of theory.

Paper Type: Literature Review

Keywords: Socially Responsible Sourcing; Sustainable Sourcing; Sustainable Supply Chain Management; Social Sustainability; Theory Application; Literature Review. 


\section{Introduction}

Socially responsible sourcing (SRS), which focuses on the upstream management of the supply chain, is an important aspect of the broader Sustainable Supply Chain Management (SSCM) agenda. The latter has been defined by authors like Carter \& Rogers (2008) to incorporate three components: social, environmental and economic performance. Thus they build on the triple bottom line (TBL) concept of people, planet and profit (Elkington, 1998) that suggests it is not enough for a company simply to be profitable. To flourish, it must also be responsible for the social wellbeing of employees, the wider community, and the natural environment. Carter \& Easton (2011) argued for the need to study all three dimensions of sustainability simultaneously. Although this is important, it is also necessary to gain a deeper understanding of some particular aspects of the sustainability agenda, particularly as this pertains to social issues in the context of SRS. Previous research has tended to focus on the environmental side, and while this remains an ongoing research field, the social side of sustainability is a growing topic area within the sourcing literature. Ergo, this paper seeks to review the literature that has included SRS to, primarily, identify the key research themes, thereby providing a timely summary for researchers and managers alike, and the research gaps that need to be addressed in the future. It also seeks to discuss whether effective use of theories is made in the existing literature, and whether, for example, authors are selecting theories appropriately from the plethora of theories available.

The vital importance of companies being aware of the social practices of their supply chain partners is clear, given the adverse publicity and lasting damage to both the brand and its trading revenues that can be caused when business practices considered to be unethical emerge in the media. This has been evidenced, for example, in the UK-based cases of Primark in 2008 and British Home Stores (BHS) in 2012, where the use of child labour by Indian suppliers was alleged; and the more recent tragedies with many workers either killed or injured in Bangladeshi factories supplying garments to Wal-Mart, Sears and Inditex in 2013. In each case, the long term damage to the brand of social malpractice is likely to have a wider, more damaging effect than just the initial 'bad press' news stories. Although the importance of being aware of social practices amongst supply chain partners is hard to dispute, there are many intrinsic challenges to incorporating social concerns into sourcing decisions. These have been highlighted by several authors and include difficulties in detecting and ensuring the implementation of desirable codes of practice, such as appropriate working conditions for employees (e.g., Jiang, 2009a \& 2009b). Thus, SRS is a challenging issue for many organisations and their suppliers, and not surprisingly an area of growing 
interest for academics, particularly given that relatively little is known about the social issues in the context of supply chain management (Hoejmose et al., 2013).

Given that others have argued for the need for organisations and researchers alike to address these social issues at the same time as considering the environmental and economic issues, it is important to further justify here the reasons for focusing this paper on the social issues alone. This justification is threefold. Firstly, whilst it is acknowledged that the three pillars of the TBL are connected and complementary, and naturally have some common drivers and barriers (Pagell \& Wu, 2009, Walker \& Jones, 2012), it is also argued here that there are some issues that are more relevant in certain contexts, e.g. social issues are more important in labour intensive sectors. Secondly, there are certain characteristics that are specific to the social agenda: like the difficulty of gauging the performance of firms regarding SRS because of the less transparent and visible nature of the results; or how the complex nature of social issues makes the implementation of changes harder in developing country suppliers, for example, because eliminating child labour in a regulated industry might shift this problem to an unregulated and more hazardous industry. Thirdly, authors such as Seuring \& Muller (2008) in their review of the SSCM literature pointed out that there is a deficit in studies focusing particularly on the social dimension of sustainability and argue for further research here. More recently research is emerging to fulfil this gap, including two papers which have explicitly focused on the social aspect of SSCM - Ehrgott et al. (2011) and Klassen \& Vereecke (2012). In the former paper, Ehrgott et al. (2011) used survey data from purchasing managers of U.S. and German corporations to test empirically how pressures from key stakeholders (customers, the government, and employees) determine the extent to which firms consider social aspects in the selection of emerging economy suppliers. Their findings suggest that middle-level supply managers play a major role in socially sustainable supplier selection, and that strong positive links exist between that selection and the investigated outcomes. In addition, Klassen \& Vereecke (2012) studied links between social management capabilities and: social responsibility, risk, opportunity, and performance; and combined their case data with earlier literature to propose an integrative framework that informs a manager's approach to social issues in the supply chain. Therefore, it is argued that this paper provides a timely review of the SRS literature, which aims primarily to assist researchers, but will also inform practitioners of the areas to which they can look to academic research for insights, and the areas which are currently lacking. Both audiences are argued to be of importance given that the managerial implications of social failures are profound. 
While comprehensive literature reviews on the environmental dimension of sustainable sourcing exist e.g. Sarkis et. al. (2011) and Zsidisin \& Siferd (2001), an equivalent review on the social dimension of sourcing only is not currently available. More recent reviews that have addressed the social issues involved in sourcing are broader as they include both the social and environmental dimensions (e.g. Carter \& Rogers, 2008; Seuring \& Muller, 2008; Carter \& Easton, 2011; Hoejmose \& Adrien-Kirby, 2012; Gimenez \& Tachizawa, 2012; Winter \& Knemeyer, 2013). Thus, all previous reviews lack sufficient insights into the specifics of SRS, given the inevitable space limitations of an academic paper. In addition, none of the previous reviews considered the appropriate use of theory within this research field. Although Carter \& Easton (2011) listed the most commonly used theoretical lenses and briefly discussed the past and potential future use of theory in SSCM, they did not consider how these theoretical lenses have helped us to understand the SRS phenomenon to date. Therefore, there is a research gap to systematically review our current understanding of SRS, including a detailed discussion of how theoretical lenses have been used in this context, leading to conclusions on how theory can be used effectively in future research. This paper thus seeks to fill this gap by addressing the following research questions:

RQ1: How has research to date contributed to our understanding of the management of socially responsible sourcing (SRS), and what are the research gaps in this area?

RQ2: How have theoretical lenses been used in SRS research? And how can theory be used effectively in future research?

As discussed above, our study's main contribution is towards greater academic understanding of SRS and the development of theory in this field, which can be summarised in three main steps with its relevance to managers highlighted in the second stage. First, peer reviewed articles from scholarly journals published between 1997 and 2013 have been classified according to their research content, with a particular focus on the use of theoretical lenses. This systematic exploration of the literature led to the identification of a more comprehensive list of issues that come under the social domain, as well as an assessment of the many terms that have been used in the literature to date. Second, a thematic analysis of the literature under five broad facets of SRS including strategy; organisational culture; risk management; transparency and performance has been carried out to determine the state-ofthe-art in SRS research. This serves as a source of reference for future researchers by providing an agenda for further work specific to the social issues, as well as providing a summary of the key research findings to date for managers in terms of the processes and implications of SRS. Third, a detailed discussion of how theoretical lenses have been used in 
the context of SRS research is outlined, leading to suggestions on how theory can be most effectively applied. From this unique critical analysis of the use of theory in the SRS literature, the following novel typology in ascending order of effectiveness is proposed theory dressing, theory matching, theory suggesting/explaining and theory expansion.

The remainder of this paper is organised as follows. Section 2 describes the systematic literature review method used to select papers along with the structure of the analysis procedure for those papers. An overview of the reviewed literature is provided in Section 3, including definitions of the various terms used in the literature to describe the SRS phenomenon. Key research themes are then described in Section 4, with the papers classified by adapting a framework previously presented by Carter \& Rogers (2008). In Section 5, the use of theoretical lenses in SRS research is discussed before the paper concludes with Section 6.

\section{Method}

The systematic literature review methodology, as described by authors such as Tranfield et al. (2003) and Denyer \& Tranfield (2009) has been used to construct a database of articles, which were evaluated in order to provide insight into our research questions. This systematic process of reviewing literature increases rigour by promoting replicability and reliability and by decreasing bias (Tranfield et al., 2003); but more importantly it makes the process transparent (Denyer \& Tranfield, 2009). In the following section we discuss the different stages that were followed while conducting the systematic literature review, as summarised in Figure 1 below.

$<$ Take in Figure 1>

\subsection{The Systematic Literature Review Protocol}

1. In the first stage of the review, a search was conducted in the abstract field of the ABI/INFORM database for the following combination of keywords: 'Socially responsible' and 'Sourcing / Procurement / Purchasing'; 'Ethical' and 'Sourcing / Procurement / Purchasing'; 'Sustainable' and 'Sourcing / Procurement / Purchasing'; 'Social responsibility / Corporate social responsibility / Triple bottom line' and 'Supply chain'; 'Social' and 'Supply chain' and 'Sustainability'. Only peer reviewed articles from scholarly journals published between 1997 till April 2013 were selected, resulting in a total of 631 relevant articles.

2. In the second stage, the duplicated results were eliminated, reducing the total number of articles to 485 . 
3. According to Denyer \& Tranfield (2009), in a systematic review it is required to set prespecified relevance and quality selection criteria. Therefore, in the third stage the abstracts of these 485 articles were read carefully and only those articles that discussed the social dimension within socially responsible sourcing and published in journals that are part of the ABS Academic Journal Quality Guide 2010 were selected. A large number of articles dealing exclusively with environmental issues were excluded. However, broader literature which considers all three dimensions of the TBL are included as well as those that consider the social dimension alone. This procedure resulted in a short-list of 120 relevant articles. Two of the authors were involved in this stage, since the decisions regarding inclusion and exclusion remain relatively subjective and it should be done by more than one reviewer as suggested by Tranfield et al. (2003).

4. In the fourth stage, the mechanical systematic literature review process was supplemented organically by including other papers that were cited in the articles identified during the third stage and judged to be relevant. This adjustment to the mechanical process is also supported by the literature as Denyer \& Tranfield (2009) point out that the review protocol should not restrict the review and the output of the search should result in a comprehensive list of core contributions which will help address the research questions. The organic addition of further papers thus sought to ensure that we included all papers relevant to our search and provided a further 37 papers, to bring the final total to 157 .

5. In the final stage these 157 articles were carefully examined in order to provide insight into our research questions of: (1) how the research to date has contributed to our understanding of the management of socially responsible sourcing, and what are the research gaps in this area; and (2) how have theoretical lenses been used in the field and how can theory be used effectively in the future. A Microsoft Excel database was created where the articles were classified into different headings and sub-headings for the purpose of analysing the trends and gaps, as described further below. For example, Table 1 shows that the 157 papers are spread across many journals. It also shows that, from a chronological perspective, overall it is possible to identify a trend of increasing focus on socially responsible sourcing to complement a more consolidated interest in green purchasing.

$\langle$ Take in Table I $>$ 


\subsection{Structure of the Analysis and Classification of the Literature}

In the full paper analysis, the first step was to analyse the terminology adopted to refer to social issues relating to sourcing; and, the specific social issues covered in the literature. The findings from this are presented in Section 3, which seeks to clarify the terminology to be used in this paper.

In order to reduce human error and bias during the analysis stage of the systematic literature review, Tranfield et. al. (2003) and Denyer \& Tranfield (2009) recommend using data-extraction forms; which should include general information about the paper e.g. title, author, publication details etc. and other specific features such as methods and themes. In the second step of the full analysis of the papers, these recommendations were followed and a classification framework for the literature was then developed to identify the:

- Research method employed;

- Research context, e.g. in a developing or developed country; and industrial context;

- Research topic, e.g. organisational culture or risk management;

- Research perspective, e.g. buyer or supplier perspective;

- Use of theory according to explanatory power.

This framework was initially created by one author and validated by the other three, based on a sample of reviewed papers. An overview of this analysis for all aspects, except the research topic, is given in Section 3, while the classification according to topic is presented in Section 4.

In terms of the classification framework, it is acknowledged that several different means of categorisation could have been used. The conceptual model proposed by Carter \& Rogers (2008) was employed as a starting point as it is considered to be the most comprehensive model that incorporates all three TBL dimensions. No models that focus only on the social dimension have been identified in the prior literature. However, given the breadth of coverage of the Carter \& Rogers (2008) model, it was not found to have the depth of categorisation that this review required. Thus it was necessary to add further sub-categories to the final classification framework employed here in order to cover all of the social issues encountered in the literature.

The model by Carter \& Rogers (2008) proposed that four facets are needed to support sustainability: strategy; organisational culture; risk management; and, transparency. The authors highlighted that these facets are not necessarily entirely mutually exclusive, and thus 
some topics may fall under more than one heading. Using these four facets as a starting point, the following eight categories and sub-categories were used:

- Strategy: (1)

- Organisational culture: Integration of values into the decision-making process and ethical behaviour (2)

- Risk management (3);

- Transparency: Reporting (4); standards (5); codes of conduct (6);

- Impact on performance (implicit in Carter \& Rogers (2008)): Relationship between practices and performance (7); measures of sustainability (8).

\section{Overview of the Literature}

\subsection{Defining Socially Responsible Sourcing (SRS)}

Social issues relating to sourcing in particular are referred to in different ways in the research literature, and sometimes the same terms are used with different meanings. The use of terms that specifically refer to the social dimension of sourcing is not common in the literature. Instead, most authors use terms with a broad scope that incorporate social issues alongside other sustainability dimensions. Table II presents the plethora of definitions that have arisen within the SSCM literature that include some or all aspects of social responsibility.

\section{$<$ Take in Table II $>$}

The definition of 'sustainable sourcing' provided by Pagell et al. (2010) is the broadest one in scope, and includes all three dimensions of the TBL. According to the authors, sustainable sourcing refers to "managing all aspects of the upstream component of the supply chain to maximise triple bottom line performance". Other terms and definitions in the table that refer to both social and environmental issues include: 'sustainable supply management' (Ageron et al., 2011; Koplin et al., 2007; Krause et al., 2009); 'Purchasing Social Responsibility' (PSR) (Carter \& Jennings, 2004; Carter, 2004; Ciliberti et al., 2008b); 'ethical sourcing' (Roberts, 2003); 'Socially Responsible Buying' (SRB) (Maignan et al., 2002; Baden et al., 2009); and, 'Socially and Environmentally Responsible Sourcing' (SERP) (Hoejmose \& Adrien-Kirby, 2012). Meanwhile, some of the terms identified focus on the social dimension of sourcing decisions: 'Socially responsible buying / sourcing' (SRB) (Park, 2005); 'socially responsible purchasing' (Leire \& Mont, 2010); 'supplier socially responsible practices' (Awaysheh \& Klassen, 2010); and, 'socially responsible supply management' (Koplin et al., 2007). 
In this paper, we restrict the remaining discussion to a hierarchy of three terms, unless the precise terminology used in previous research is relevant to the conclusions of the literature review. The three terms are as follows:

a. Sustainable SCM (SSCM) - the broadest term, as defined in the introduction;

b. Sustainable Sourcing (SS) - all three TBL dimensions, upstream only;

c. Socially Responsible Sourcing (SRS) - social dimension of the TBL, upstream only.

Like the use of terminology, the coverage of social issues can also vary significantly, ranging from dealing specifically with one (or more than one) aspect of SRS, to a more general approach to the subject, i.e. referring to the social dimension as a whole. According to the classification proposed by Carter \& Jennings (2002) and Carter (2004), the following categories of social issues can be identified:

- Human Rights: labour conditions such as child and forced labour, discipline, working hours and freedom of association (e.g. van Tulder \& Kolk, 2001; Winstanley et al., 2002; Kolk \& van Tulder, 2004; Luken \& Stares, 2005; Fukukawa \& Teramoto, 2009; Awaysheh \& Klassen, 2010; Isaksson et al., 2010; Robinson, 2010; Brammer \& Walker, 2011);

- Safety: the provision by suppliers of safe working environments and regular health and safety employee training (e.g. Johnson, 2004; Welford \& Frost, 2006; Hutchins \& Sutherland, 2008; Krause et al., 2009; Bai \& Sarkis, 2010; Leire \& Mont, 2010);

- Community: includes charitable initiatives, like auctioning or donating gifts received from suppliers, or economic development, such as the use of local suppliers (e.g. Maloni \& Brown, 2006; Castka \& Balzarova, 2008; Ciliberti et al., 2008a; Ciliberti et al., 2008b; Lim \& Phillips, 2008; Walker \& Preuss, 2008; Ketola, 2010; Pullman \& Dillard, 2010; Tate et al., 2010);

- Diversity: purchasing from minority/female-owned business enterprises (e.g. Maignan et al., 2002; Carter \& Jennings, 2004; Ciliberti et al., 2008b; Brammer \& Walker, 2011);

- Ethics: ethical behaviour in sourcing decisions, including purchasing through the fair trade movement, which supports pricing strategies that allow suppliers to avoid poverty and sustain business longevity (e.g. Carter, 2000b; Kaptein, 2004; Maloni \& Brown, 2006; Pretious \& Love, 2006; Castka \& Balzarova, 2008; Ciliberti et al., 2008b; Drake \& Teepen Schlachter, 2008). 
In addition to the above categories (from Carter \& Jennings, 2002; Carter, 2004), the following issues have also been identified in the reviewed literature:

- Respect for local democratic institutions, which would arise when purchasing items from companies that are not acknowledged by established democratic institutions (Maignan et al., 2002);

- Animal welfare concerns (Maloni \& Brown, 2006; Pullman \& Dillard, 2010);

- Social impact on customers, such as through suppliers using unsafe paint on toys with consequences for the consumer (Klassen \& Vereecke, 2012).

It is argued here that all of these social issues are important in the context of SRS although, realistically, priority is likely to be given to one or two categories of issues in the early stages of an SRS initiative. Further research into the relative importance of the various issues could provide valuable insights for practising managers.

\subsection{Research Context, Perspective and Method in the Reviewed Papers}

Tables III and IV present an overview of the research methods, use of theory, research context and perspective used in the reviewed papers. Focusing initially on Table III, in terms of research method, it indicates that the number of purely theoretical contributions is limited to 30 papers. This category includes five literature reviews on SSCM by Seuring \& Muller (2008a), Carter \& Easton (2011), Gimenez \& Tachizawa (2012), Hoejmose \& Adrien-Kirby (2012), and Winter \& Knemeyer (2013). Conceptual models are proposed in three of these reviews (Seuring \& Muller, 2008a; Carter \& Easton, 2011; Hoejmose \& Adrien-Kirby, 2012). However, as none of those reviews is exclusively focused on the social dimension, there seems to be a lack of solid theoretical background in the area.

$<$ Take in Table III>

$<$ Take in Table IV>

Of the papers using an empirical research method, most (107) are based on primary data, mainly case study-based (58) or survey-based (37). Only 6 of the empirical studies used other methods, either: grounded theory, action research, a Delphi study or an ethnographic study. The use of multiple primary research methods (mixed methods) is extremely limited, having been identified in only 6 of the papers (Carter \& Jennings, 2002a; Tencati et al., 2008; Baden et. al. (2009); Birkin et al. (2009); Lee \& Kim 2009; Tsoi, 2010). Finally, 26 of the 157 contributions analysed used secondary data to support their arguments, mainly based on content analysis. The types of secondary sources used often include corporate and supplier 
codes of conduct and sustainability reports rather than interviews with suppliers in the supply chain. In 6 papers (Graafland, 2002; Kolk \& van Tulder, 2002b; Leire \& Mont, 2010; Winstanley et al., 2002; Panapanaan et al., 2003; Rimmington et al., 2006), both primary and secondary data were used.

As shown in Table III, the use of theory is extremely limited and has been detected in only 24 papers. The adoption of theoretical lenses in the reviewed contributions will be discussed in detail in Section 5; however, there is scope for the application of more theory in this area.

In terms of the research context, amongst the papers based on primary data, most studies have been conducted in the context of developed countries. Only a minority (21) have focused purely on developing economies. In terms of research perspective, most papers adopt (either explicitly or implicitly) a focus on buyers' challenges and opportunities, while the supplier's perspective has been taken into account in only 17 contributions. A multistakeholder's perspective, including analyses of dyadic relationships between buyers and suppliers, is even rarer having being identified in only 12 articles. Thus it is argued that there is a need for more research that considers the supplier's perspective, particularly where that supplier is located in a developing country.

Table IV further analyses the research context by classifying the reviewed papers according to the industrial context studied. Out of the 107 empirical papers based on primary data, 47 have researched SRS policies and practices with a specific industry focus; while 22 of them used a multi-industry design, again specifying the industrial context. The remaining empirical papers do not specify any particular industrial sector, but instead focus for example on SMEs (e.g. Pedersen, 2009), or on members of an industrial affiliation (e.g. Carter, 2004) and therefore it is not possible to include these papers in this part of the analysis. Within the 69 papers that do specify the industrial context, the number of times firms from each type of industry have been researched (frequency) and, for each industry, the percentage that adopted a single industry focus compared to the percentage that used a multi-industry design, are also presented in Table IV. This analysis shows that the main emphasis of academic scrutiny has been in the apparel (e.g. Graafland, 2002, Kolk \& Tulder, 2002, Jiang, 2009) and food sectors (e.g. Maloni \& Brown, 2006, Lamberti \& Lettieri, 2009, Pullman \& Dillard, 2010); which is perhaps unsurprising given the generally labour intensive nature of these industries. Table IV also emphasises the previously discussed general trend for the majority of studies to have a developed country focus (69.5\%), illustrating that this is the case across all the specific industries studied. In addition, the table illustrates that all the 'pure' service industries 
including health-care, consultancy/IT services, and other miscellaneous services (e.g. tourism, catering, logistics, banking etc.) together only feature 16 times (13.5\% given the overall frequency of 118) and surprisingly there is not a single study in the service sector which occurs in a developing country context. These gaps in the literature reflect a need to study the implications of SRS in the service sector especially with the mushrooming of business process outsourcing of services like call centres, software development and medical transcription in emerging markets such as India, China and the Philippines. These industries are generally thought to be slackly regulated, have long working hours and there is intense pressure on performance in terms of efficiency. Thus this sector provides a rich setting to investigate how Western firms which outsource services to developing countries are looking after the social needs of their supplier's employees.

This overview has given an indication of potential areas for future research on the basis of the number of papers taking a particular perspective; considering a particular type of country or industrial context or adopting a theoretical lens. However, this analysis now needs to be strengthened by considering whether this applies to all topics within the SRS area, or whether some topics have been explored in more detail than others. This is discussed in the next section. For readers who wish to identify all of the papers that consider developing countries, and include a supplier's or a multi-stakeholder's perspective, an Appendix is included. This lists all of the papers included in the review alphabetically and indicates the key aspects of their context and perspective, as well as the research topics covered.

\section{Socially Responsible Sourcing (SRS) Research Topics and Research Gaps}

A classification of the reviewed literature according to the 8 categories listed in Section 2.2 is summarised in Table V, with further details given in the Appendix. As shown in the table, most contributions fall into the areas of 'Strategy' and 'Transparency', while less populated areas include 'Impact on Performance' and 'Organisational Culture'. 'Risk Management' is the least populated area, with only 8 contributions. Each of the areas analysed will be discussed in turn in the following subsections. In each subsection, we do not attempt to comprehensively discuss all of the papers included in the Appendix, but instead we focus on describing some of the key literature contributions and conclude by identifying gaps and suggesting potential future research areas.

\section{$<$ Take in Table V>}




\subsection{Strategy}

Carter \& Rogers (2008) emphasised the importance of integrating an organisation's sustainability strategy with its corporate strategy. Similarly, according to Andersen \& Skjoett-Larsen (2009), practising Corporate Social Responsibility (CSR) in supply chains requires that CSR is embedded within the entire organisation. In particular, the importance of integrating internally and externally oriented strategies (such as the internal organisational culture with supplier partnership management) to manage CSR issues is emphasised by authors such as Holt (2004), Leire \& Mont (2010) and Park-Poaps \& Rees (2010).

As well as ensuring that the overall sustainability strategy is embedded and integrated in an organisation, it seems equally important to be able to identify specific strategies in relation to SRS. Specific frameworks for classifying SRS strategies are provided by Maignan et al. (2002), Ciliberti et al. (2008a), and Winstanley et al. (2002). Firstly, Maignan et al. (2002) identified the following four approaches: Reactive (denying the relevance of any stakeholder issues to the organisation and any responsibilities); Defensive (implicitly acknowledging the existence of stakeholder issues, but not addressing them); Accommodative (addressing stakeholder issues as long as they do not impair organisational processes or negatively impact economic performance); and, Proactive (systematically anticipating, monitoring and addressing stakeholder issues). Maignan et al. (2002) described the benefits that adopting a proactive SRS strategy can have for an organisation in terms of reputation, marketing and the stimulation of innovation; although recognising that different strategies may be needed in different contexts. Other studies that also considered proactive strategies include: Harwood \& Humby (2008) and Park-Poaps \& Rees (2010). Secondly, Ciliberti et al. (2008a) identified two main strategies that can be used for transferring socially responsible behaviour across the supply chain: compliance with requirements; and, capacity building. The former approach consists of setting standards for suppliers and implementing strict monitoring programs to ensure compliance. The latter approach was also discussed by Andersen \& Skjoett-Larsen (2009) and aims to build the supplier's own abilities for handling SRS issues; for example, by promoting a socially responsible culture amongst suppliers. Thirdly, Winstanley et al. (2002) identified two possible corporate approaches to human rights, and, specifically to child labour in the supply chain: indifference (choosing not to act or act with reluctance in support of human rights), and involvement (actively taking steps to identify and monitor human rights issues upstream in the supply chain).

Amongst the contributions that focused on SRS strategies, only a limited number addressed issues related to the implementation of such strategies. In particular, barriers and 
challenges to the integration of social standards into sourcing decisions have only been marginally investigated. Examples of studies that do look at barriers and challenges include: Harwood \& Humby (2008) and Carter \& Jennings (2002). The former identified three main types of barriers: 'associated costs' leading to a need to prioritise resources; 'uncertainty' over what social responsibility exactly entails; and 'cultural and management issues', including problems of ownership, inertia and cynicism. However, neither of the above studies considered the implementation of SRS strategies within a developing country, nor did they take a supplier perspective. The same is true of the majority of papers discussed above that propose SRS strategies (with the exception of Winstanley et al., 2002) and hence further research is needed that considers alternative contexts and perspectives both when implementing SRS strategies and developing new ones.

\subsection{Organisational Culture}

Organisational culture, which includes values and ethics, is a fundamental driver of SRS practices (Carter \& Jennings, 2004; Svensson, 2009). In the current scenario of global outsourcing, stakeholder expectations have increased, thereby exerting external pressure on organisations to be ethical and causing sourcing managers to be held responsible not only for their own actions, but also those of their suppliers (Goebel et al., 2012). This relevance of organisational ethics and values, together with the fact that day-to-day decisions are essentially made internally by individuals, makes it important to address two themes: the alignment between organisational and individual values; and, the mechanisms through which values are incorporated into decision-making. Each of these two areas is discussed below.

The co-existence of organisational and individual values in relation to social responsibility and the possible dichotomy between them has been discussed by authors such as Harwood \& Humby (2008), Carter \& Jennings (2002) and Park (2005). According to Harwood \& Humby (2008), individual values and personal interests can give the socially responsible practices adopted by an organisation a particular focus in terms of the specific social issues addressed (e.g. a specific focus on labour conditions rather than safety-related issues). Carter \& Jennings (2002) found that logistics managers, driven by their personal values and morals, can implement socially responsible practices even when the organisational culture acts as a barrier. The contribution by Park (2005) is one of few studies to look at the interactions between individual ethical beliefs and organisational signals that prompted a reaction in terms of their SRS practice. However, this research was conducted in a developed country context, and further research is needed in the context of developing countries; since it 
has been argued that there is greater tendency and more scope for public officials in developing countries to behave unethically, especially to indulge in corruption (Ntayi et al., 2013). There has also been comparatively few studies on ethical procurement practices in public sector organisations compared to the private sector and hence this is also another interesting area for future research as the organisational culture can be very different in this context (Walker \& Brammer, 2009; Brammer \& Walker, 2011; Preuss \& Walker, 2011).

If there is a general consensus on the relevance of organisational and individual values in driving and promoting socially responsible practices, the mechanisms through which values can be incorporated into actions and decision-making have been only marginally investigated. Amongst the reviewed contributions, only the studies by Pullman \& Dillard (2010) and Wu \& Pagell (2010) analysed how broad values translate into principles and rules that can in turn guide sourcing decisions. While the focus of Pullman \& Dillard (2010) is on the organisational structures (i.e. rules and resources) that can enable and constrain actions, $\mathrm{Wu}$ \& Pagell (2010) looked at how sustainability issues are integrated in supply chain decisionmaking and how the trade-off between short-term profitability and long-term sustainability objectives is managed by decision-makers. Although the main focus of Wu \& Pagell (2010) is on environmental issues, the study also included the social dimension of sustainability thereby suggesting the possibility to transfer conceptual tools from the environmental area into the social one. However, further research is required to understand whether the translation mechanisms are exactly the same in the two areas and what role values actually have in promoting effective SRS practices. A worthwhile avenue for further research might be the expansion of the recent organisational learning theory of absorptive capacity (as described by Zahra \& George, 2002) to explain how effective organisational learning processes identify, disseminate and integrate relevant external and internal knowledge; and thus influence the implementation of SRS in increasingly turbulent business environments.

\subsection{Risk Management}

Risk Management is concerned with the awareness and potential control of risks within a company's scope. Its importance within the context of SRS is highlighted by the authors included in this review. For example, according to Spekman \& Davis (2004), a range of supply chain-related risks should be considered as endemic. In particular, six dimensions of supply chain-related risk that need to be managed were identified, including the ethical dimension. In addition, Carter \& Rogers (2008) described the ability of an organisation to understand and manage its social risk in the supply chain as fundamental to its 
competitiveness. Despite the relevance of this, the attention given to this topic is extremely scant. Only 8 of the reviewed papers focus explicitly on risk management issues (Table V ). As well as the importance of risk management in this context, two other themes emerge in the literature: the use of formal tools for SRS risk management and risk reporting.

The contributions by Koplin et al. (2007) and Harwood \& Humby (2008) are the only academic papers that have presented formal tools to incorporate risk management into the sourcing decision-making process. Based on the analysis of Volkswagen AG's supply management system, Koplin et al. (2007) highlighted a need for detecting supply related ethical risks at an early stage. According to the authors, this could be achieved by implementing internal and external social issue screening procedures, with centralised information management systems. Harwood \& Humby (2008) emphasised the importance of considering 'cost risk', in addition to cost, when making sourcing decisions by introducing the concept of 'risk efficiency', which could reduce the conflict between social responsibility and more traditional procurement measurement systems. Both of the above contributions are based on case study analysis, mostly in developed countries, and thus there is much scope for further research into this topic in other contexts, particularly including developing countries.

In terms of risk reporting, Tate et al. (2010) described the potential usefulness of CSR reports to both focal organisations and stakeholders. Companies use such reports to reassure both internal and external parties that their social expectations are being met. Indeed, this also provides stakeholders with an understanding of the risks to which organisations are exposed, and how they manage such risks. The role of reporting risks will be further discussed in the following sub-section on transparency.

Ultimately, social risk, like any other business risk, is a trade-off to be addressed by an organisation, and, in the light of recent brand equity disasters, should be addressed across the whole of the supply chain equally. The implications of cost versus risk are, seemingly, as important for social risk as they are for environmental risk - perhaps even more so as we are dealing with people's lives here. Therefore, risk management in the context of SRS has never been more important. This leads to a need for further research in this area, specifically focussing on formal tools that can be adopted to incorporate risk management into the sourcing decision-making process.

\subsection{Transparency}

According to Carter \& Rogers (2008), transparency refers not only to reporting to stakeholders, but actively engaging stakeholders and using their feedback to improve supply 
chain processes. This should imply that economic, social and environmental issues are transparent and visible to partners and customers, and open to public scrutiny. But this is not always the case. In response to stakeholder pressure for responsible sourcing, firms have initially proposed three potential ways to achieve transparency: (1) by publishing annual CSR/sustainability reports (Tate et al., 2010); (2) by developing internal/CSR codes (Lee \& Kim, 2009) and private supplier Codes of Conduct (CoC) (Gugler \& Shi, 2009); (3) by resorting to other certification or standards (Ciliberti et al., 2009) to 'endorse' their company stance via third-party accreditation. Adherence to the codes or standards is usually made a requirement for securing orders, especially if they are situated in distant developing countries (Ehrgott et al., 2011). This has led to firms adopting various implementation processes (e.g. monitoring, auditing, collaboration) to ensure that their suppliers are complying with their CoCs or other external social standards. Therefore, we have divided the reviewed papers on transparency into three distinct areas of analysis - reporting, standards and codes of conduct (Table V). These three areas are discussed in turn below, followed by the problems associated with auditing and/or inspecting suppliers and the consequences for the careful implementation of CoCs.

Firstly, in terms of reporting, the research has focused on the potential effectiveness of non-financial CSR/sustainability reports. For example, Belal (2002), after evaluating 13 social reports published in 1999 by large UK firms, concluded that social reporting is used as a legitimisation device, and to manage stakeholders effectively, rather than necessarily to ensure sustainability. Thus reporting is not necessarily a successful means of achieving the transparency that stakeholders may demand and other means are needed.

The implementation and effectiveness of social standards have been researched by authors such as Ciliberti et al. (2009). They studied the implementation of SA8000 - the global social accountability standard, encouraging firms to develop and maintain socially acceptable workplace practices in Italian SMEs. They found that standards facilitate coordination and increase transparency between immediate partners in a supply chain but not with second- or third-tier partners. Stigzelius \& Mark-Herbert (2009) explored the motives, obstacles and opportunities of implementing SA8000 in Indian garment manufacturers demonstrating that there is a business case for higher legal and social compliance, as it may lead to decreased labour turnover and increased orders. In addition, Castka \& Balzarova (2008) determined a set of theoretical propositions about the diffusion of the comparatively newer ISO26000 social standard (released in November 2010), but empirical research is needed to validate these propositions. Mueller et al. (2009) assessed four different standards 
(ISO14001, SA8000, FSC and FLA) and concluded that all of the standards have some form of deficit; but, particularly ISO14001 and SA8000, which demonstrate low legitimacy among external stakeholders. Thus it can be concluded that, as yet, these standards are also not achieving SRS in the manner that was perhaps initially hoped and more research is needed.

An increasing amount of attention in the literature has been given to the content and implementation process of company CoCs. Research in terms of the contents of CoCs includes: Sobczak (2003), Preuss (2009), and Kaptein (2004). For example, Preuss (2009) analysed the ethical sourcing codes adopted by FTSE100 companies and found that, at a macro level, CSR issues are covered extensively, but at a micro level there is a degree of selectivity in the issues being addressed. In terms of the implementation of CoCs, Jiang (2009a, 2009b) conducted an extensive study into Chinese suppliers, and discovered that even though code enforcement through buyer-to-supplier governance can minimise suppliers' opportunistic behaviour (e.g. double book keeping); it only encourages suppliers to do 'just enough' to avoid being caught, thereby failing to increase sustainability in the long term. The latter research further revealed that a hierarchical governance model, and a shift from threat towards collaboration, leads to better compliance. Meanwhile, the effect of codes on the incidence of child labour has been dealt with thoroughly by the authors Kolk \& van Tulder (2002a, 2002b, 2004), who argued pertinently that a stricter approach involving firing child workers or terminating relationships with suppliers that employ them does not change the underlying causes. Codes must be specific, strictly implemented, monitored and combined with alternative arrangements for under-age child workers. The cultural context of the host country should also be taken into account.

There has been research exposing the limitations of the auditing and inspection process (Welford \& Frost, 2006, Boyd et al., 2007, Kortelainen, 2008); and alternative solutions to increase transparency have also been proposed. For example, from a buyer's perspective Mamic (2005) highlighted the role of training and education as effective catalysts for code development and implementation; Graafland (2002) demonstrated that a semi-independent auditing organisation increases transparency and reliability, when compared to a dependent or third party auditor; and Colwell et al. (2011) found that the relationship between ethical code enforcement and continued commitment is positively related. Dyadic relationships between developed country MNCs and developing country suppliers during code implementation have also been explored, but to a lesser extent. For example, Lim \& Phillips (2008) presented case study analyses of four of Nike's Korean and Taiwanese suppliers and found an 'arms-length' approach to implementing $\mathrm{CoC}$ to be ineffective; while $\mathrm{Yu}$ (2008) conducted an explanatory 
study of the implementation of Reebok's labour-related $\mathrm{CoC}$ at one of its major Chinese suppliers and found that the main barriers to implementing social sustainability were: the buyer's intentions to reduce costs and maximise profitability; competition amongst suppliers (e.g. to reduce costs); and a lack of government enforcement of labour laws. Further research is needed to consider how to effectively overcome such barriers.

In summary, future research can look for ways to determine and increase the level of transparency in these codes and standards, thereby reducing the transaction costs of implementation. In particular, it is important to further examine the extent to which CoCs and third party certifications developed in the West apply to developing country suppliers with different cultural and socio-economic values; and, how they can be effectively implemented. Previously, there have been a limited number of dyadic studies that have focused on this issue, and even fewer have adopted a multiple stakeholder perspective; where such stakeholders can include NGOs, donor agencies, third party auditors, consultants, etc. Many of these stakeholders are professional service providers and their role in promoting/ implementing socially responsible sourcing is an under-researched area. Therefore additional research needs to be carried out to understand the various stakeholder/institutional pressures causing firms to be transparent (or not) while sourcing responsibly from developing country suppliers.

\subsection{Impact on Performance}

As indicated in Table V, the impact on performance is split into: the relationship between SRS and performance; and SRS metrics. The former has been discussed by a number of authors, including Maignan et al. (2002), Luken \& Stares (2005) and Carter \& Rogers (2008). In terms of the specific nature of the relationship between SRS and performance, only Maignan et al. (2002) has considered this in detail, describing advantages such as the stimulation of innovation and avoidance of negative publicity. The other authors in this area have discussed whether SRS has a positive or negative impact on economic performance. Positive impacts suggested by authors such as Carter \& Jennings (2002), Carter \& Rogers (2008) and Carter \& Easton (2011) include long-term improved economic performance and improved trust with stakeholders. However, according to Luken \& Stares (2005), the business case for sustainability appears weaker in the social area than in the environmental one. This can be due to the fact that the benefits expected from social initiatives are mainly long-term and often intangible; this can make formalising the actual impact, in terms of economic results, more complex. According to Wittstruck \& Teuteberg (2011), the financial success of 
investments in sustainable initiatives is also relatively uncertain; this can make companies that are subject to significant cost pressures decide against such investments. Thus more research is needed into the benefits of SRS, and specifically into finding ways to achieve economic and social sustainability at the same time.

The number of contributions that have adopted a supply chain perspective for measuring social sustainability is extremely limited (8; see Table V). For example, Ketola (2010) proposed five levels of holistic responsibility, according to the percentages of fair trade, fair production and fair sales, compared with the total values of purchases, production and net sales, respectively. Also, Hutchins \& Sutherland (2008) proposed a method to evaluate the social sustainability of a company's supply chain. This involves firstly obtaining a social sustainability measure by value-weighting four main indicators (labour equity, healthcare, safety, philanthropy). However, this clearly does not include all of the components of social issues, as identified in Section 3.1 above. More recently, Wang \& Sarkis (2013) used a relatively large data set of publicly available data from US-based companies to investigate the financial benefits associated with individual and joint environmental and social SCM activities. Even though the authors did not find a direct relationship between social SCM practices and organizational financial performance, they found that integrated SSCM i.e. jointly including social and environmental SCM efforts is positively associated with corporate financial performance. This is a somewhat interesting finding, since jointly implementing both programs is usually more expensive than individual programs. An explanation for this might be that the general synergistic relationship between the programs leads to decreased incremental costs and a better understanding of the processes involved over time (Wang \& Sarkis, 2013).

In conclusion, our review has highlighted a need for further research in both of the directions identified in the literature. In relation to the first direction, further research is required that analyses and quantifies the economic impact of SRS practices. This would allow for a better understanding of the inter-dependencies between social and economic KPIs (Wittstruck \& Teuteberg, 2011), and the extent to which there is a business case for social responsibility (Roberts, 2003). In relation to the second research stream, there is a need for further attempts to formalise supply chain social sustainability and develop indicators or scoring mechanisms that can complement organisational measures. There are also a number of dimensions identified in Section 3.1 that have not yet been included in the SRS performance metrics literature, such as diversity and social impacts in the community in which the firm operates. Future research needs to embrace performance metrics which 
includes those affected outside of the immediate firm and members of the supply chain, for example, how these measures are influencing the standard of living of workers and their families.

\subsection{Summarising the Conclusions Regarding Research Question 1}

In terms of our current understanding of SRS, this literature review has shown that a clear understanding of its strategic relevance has been established, as has the need for greater transparency given the interest of many different stakeholders in the social responsibility area. However, in other areas contradictory conclusions have been reached, such as whether implementation of an SRS initiative will have a positive or negative impact on economic performance. Thus there are a number of areas of future research that were derived from the above discussion and the overview of the literature presented in Section 3, as summarised here:

- In general: there is a clear lack of empirical studies with an explicit focus on developing economies from a supplier's or, indeed, a multi-stakeholder's perspective. More research needs to be conducted in the service sector, especially on the social implications of Western firms outsourcing services to developing countries.

- Strategy: implementation of strategy has received the least attention, and needs to be further investigated, especially in developing economies.

- Organisational Culture: more research is needed into the means of transferring values into mechanisms for decision-making, especially looking at whether the mechanisms being used for environmental issues can also be applied to the social dimension and how the absorptive capacity (as described by Zahra \& George, 2002) of the focal firm and its suppliers affect implementation.

- Transparency: further cross-national patterns of implementation of social standards need to be investigated, specifically the implementation of Western-based codes and certifications into developing country suppliers, characterised by differing cultural and socio-economic values; and the roles of multiple stakeholders including professional service providers, in this implementation process.

- Risk Management: there is a need to develop formal tools that can be adopted to incorporate risk management into the SRS decision-making process.

- Impact on Performance: further research is required that analyses and quantifies the economic impact of SRS practices, and formalises supply chain social sustainability by 
developing appropriate performance metrics that reflect the social impacts on stakeholders beyond the immediate supply chain.

In addition, our study earlier revealed that the use of theory in the papers analysed is extremely limited. This calls for further investigation into this specific area, as discussed in Section 5 of the paper below.

\section{Use of Theoretical Lenses in the Reviewed Articles}

There is an increasing tendency within the Operations Management (OM) community to include references to theories within research papers, often borrowed from other academic disciplines. However, the value of theory within OM research has been questioned by Schmenner et al. (2009), who argued that theory is sometimes used inappropriately and does not necessarily add to our understanding of the phenomenon being studied. Their controversial paper stands out given that the majority of authors call for more use of theory, without raising any such concerns. For example, Barratt et al. (2011), in the context of a review of qualitative case studies in OM, argued that the use of theory can lead to stronger conclusions in the form of a framework or set of propositions. Without a theory, they argued that papers are more likely to conclude with less valuable descriptive insights. Thus, it is implied that papers that make use of a formal theoretical lens are always better papers than those that do not. Given then that there are varying viewpoints on this topic between Schmenner et al. (2009) and authors such as Barratt et al. (2011), it is important to question the extent to which the use of one or more theoretical lenses adds to the strength of a paper's findings. This section seeks to discuss the second research question outlined in Section 1 regarding the effective use of theoretical lenses in the context of the SRS literature.

Before beginning this discussion, it is essential to clarify that the focus is on the use of pre-existing theories that provide a theoretical lens for the research undertaken. Hence, papers which develop their own theory via propositions, etc are not included unless they make use of a pre-existing theory. The list of such theoretical lenses found in the SRS literature is given in Table VI, along with a complete list of the papers that refer to them. We include only papers that make explicit use of such theories, excluding papers that could be argued to make implied use. For example, Anderson \& Skjoett-Larsen (2009) explored contingency factors, but did not explicitly mention contingency theory and thus are not included in Table VI or the discussion below. In Table VI, we focus on the main theories, but for completeness also list associated sub-theories that are also mentioned in their own right. For example, as well as the Resource Based View (RBV), we include the related 'population ecology theory' and the 
'resource dependency theory', as explicitly referred to by Carter \& Rogers (2008). For definitions of each of the theories, and seminal references, the reader is referred to the SRS references given in Table VI.

\section{$<$ Take in Table VI>}

\subsection{Classification of Theory Use within the Reviewed Papers}

The use of theory is classified into four types in the discussion that follows:

- Theory dressing;

- Theory matching, for validation purposes;

- Theory suggesting and explanation, to develop propositions or hypotheses etc;

- Theory expansion.

Each of these types is defined and explained in turn below, using examples from the reviewed literature.

The first and weakest use of theories observed is as 'theory dressing', which entails the simple mention of a theory without further expansion of its application to the research findings (Harwood \& Humby, 2008; Ciliberti et al., 2008b). In the case of stakeholder theory, this could be argued to be justified given that it has been described as a cornerstone of the sustainability debate (Vurro et al., 2009). However, describing such research as 'theorydriven' would be to over claim, as the simple mention of a theory in this way neither helps to build or test theory, nor to add concrete external validity to the research. Thus no explanatory power is added, and while this name dropping of theories does no harm, it appears to add nothing of substance to the research findings.

The second use of theory found in the reviewed articles is classified here as 'theory matching'. This use of theory adds external validity to the research findings as it illustrates that the findings reported in the research paper have features in common with pre-existing theories (Barratt et al. 2011). This use of theory adds research rigour, though it does not add explanatory power to the research findings. A good example of this is found in the paper by Pullman \& Dillard (2010), who used structuration theory in the context of a study of sustainability in the beef supply chain. They described the theory in some detail, explaining that structures in the form of rules can provide "normative legitimacy (legitimation) and meaning (signification)", while resources (domination) may include both human and material resources. These concepts were then translated into specific issues included in a framework developed in the paper to describe a value driven organisation. Thus, for example, legitimation is described in terms of the norms and values of the organisation, which include 
family (cattle) ranching cultural values, economic sustainability and environmental conservation. Similarly, the rules for action included 'graze well' principles for the cattle ranches - a rule which all members of the organisation agreed to follow. This use of theory adds external validity to the arguments of the paper, as it demonstrates a high level of consistency between the findings of this study and an existing theory (Barratt et al., 2011). However, the use of theory by Pullman \& Dillard (2010) does not add anything to our understanding of the SRS phenomenon. Instead greater understanding comes from the descriptive insights provided, which are extremely pertinent in themselves, providing rich insight into how practicing managers might achieve socially responsible practices in this context.

The third use of theory is classified here as 'theory suggesting and explanation'. In this case, the theory can be used in inductive research to suggest explanations for the results (e.g. Pagell et al., 2010); or more commonly, for deductive research. In the latter papers, the theoretical lens is a clear starting point for the research, thus the research is theory-driven, and informs the development of hypotheses, propositions, interview protocols and/or conceptual frameworks. An interesting and novel example of this is given by Boyd et al. (2007) who used procedural justice theory to develop a conceptual model to help supply chain managers implement ethical codes in their supply chains. In this case, no empirical data was collected to draw conclusions, but the paper presented a new understanding of sustainability issues and hence provided a good starting point for further research. Similarly, Carter \& Rogers (2008) used elements of four theories (Transaction Cost Economics (TCE), $\mathrm{RBV}$, population ecology \& resource dependence theory) in an integrated manner to explain why all three aspects of the TBL may be essential to sustainability in the supply chain. Their approach to the inclusion of theory could be argued to be somewhat 'pick $n$ mix' and consequently the arguments linking the theories to the propositions vary in their depth of discussion. For example, it can be argued that compared to the other three theories, Carter \& Roger's (2008) application of population ecology theory to suggest a future research proposition is somewhat shallow as it lacks sufficient explanation. Similarly, De Bakker \& Nijhof (2002) take a 'pick $n$ mix' approach by selecting both stakeholder theory and RBV in order to deductively present a framework for assessing organizational capabilities required to address and identify relevant stakeholder demands in terms of responsible chain management. The authors first turned to the wider stream of RBV literature, but in order to build their concept of organizational capabilities they focused only on the capability literature, which is a subset of RBV. Here, their use of only a part of the RBV theoretical framework could have 
implications for the application and results of the findings. In contrast, the paper by Pagell et al. (2010) showed that TCE and RBV respectively provide opposing short term and long term explanations of their findings, but by adding the stakeholder theory perspective they were able to strengthen the debate and offer a hybrid solution. Thus the extent to which the use of theory (either in a 'pick $n$ mix' fashion or by using one or more complete theories) strengthens the debate can be variable, even within the same paper. For 'theory suggesting and explanation' to be effective use of theory, the link between the theory and the propositions/ hypotheses needs to be very clear and convincing, otherwise this use of theory should be classified as 'theory dressing'.

In addition to developing propositions and conceptual models, papers in this category may also be used to aid in the explanation of empirical research findings, and these are argued to be the strongest papers in this category. A good example is provided by Jiang (2009a), who made detailed use of TCE, referring to bounded rationality; opportunism and asset specificity in some detail, to develop and justify a conceptual model and a series of hypotheses to explain how governance relationships lead to supplier compliance with supplier CoCs imposed on them by the buying organisation. The model was then tested using structural equation modelling using data from both (i) suppliers that have been known to comply with CoCs and (ii) suppliers whose contracts have been terminated due to non-compliance. It concludes convincingly that 'if buying firms are not part of the solution, they are part of the problem'. In other words, non-compliance is often caused by the buyers themselves who, for example, execute audits leaving suppliers with an unrealistic set of 'problems' to solve, offering no assistance in carrying out the improvements, no negotiation over realistic time frames, and so on. This is argued here to be one of the strongest papers included in this literature review. Effective use of the TCE theory is one reason for its strength; however, the paper is unusual in that it took a supplier perspective and it is this that makes it stand out, providing greater insights into the reasons for the failure of previous practices. This leads to much more practical and insightful implications for the buying firms. Thus it is noted that while the use of theory is a strong contribution to this paper, adding important explanatory power, this is not the only key strength.

The fourth use of theory found in the SRS literature is classified here as 'theory expansion'. It is argued that this is the strongest use of theory as it makes the most powerful contribution in aiding understanding of the SRS phenomenon; thereby enabling managerial implications to be derived by the use of a theoretical lens. Here, the theory may shape the design of the data collection or its relevance may have emerged after the data was collected. 
Thus this use of theory may go alongside 'theory suggesting and explanation' or may be used independently. An excellent example of this use is presented by Mueller et al. (2009) who used legitimacy theory to investigate whether standards, such as SA8000 and FLA (Fair Labour Association), provide reassurance to customers. Five legitimacy criteria were used to assess each standard; for example, inclusivity and discourse were described as ways to include stakeholders in the development of a standard, thereby increasing confidence in its coverage of all appropriate criteria; control is the means by which the standard is implemented and includes issues of impartiality on the part of the assessors; and supply chain and transparency assesses the extent to which the standard includes all members of the supply chain and the level of transparency/visibility of the results. While the definition of legitimacy theory alone would not have added power to this discussion, it is suggested here that by considering a more precise definition of the theory for this context, in the form of the five criteria, the discussion is greatly strengthened. Clear conclusions were then drawn on how the use of these standards could be improved to increase customer confidence and hence enable the standards to be a better means of legitimising sustainable business practices in the supply chain. Similarly, Belal (2002) made powerful use of stakeholder theory by using it to consider the extent to which social audits meet the needs and expectations of stakeholders. He made a distinction between stakeholder management, whereby the firm simply aims to do sufficient to keep the customer loyal and hence to prevent adverse effects on profitability; and stakeholder accountability, whereby the firm is committed to the values of the stakeholder and feels a deeper responsibility for sustainability issues. The author concluded that current auditing methods tend to focus on stakeholder management and that there is much progress needed to move towards full accountability. Vurro et al. (2009) made similarly strong use of stakeholder theory by extending stakeholder network theory to inform their discussion to explain the type of sustainable supply chain governance models that are used by organisations.

\subsection{Choosing an Appropriate Theory and Justifying that Choice}

Having argued that the most powerful use of a theoretical lens adds explanatory power and leads to important managerial conclusions, a note of caution is now needed. This arises because the choice of theory can make a difference to the conclusions drawn. This point comes out strongly in the paper by Pagell et al. (2010), which demonstrates that the RBV and TCE can provide conflicting explanations. By adding in stakeholder theory, Pagell et al. (2010) were able to reconcile their otherwise opposing conclusions. Thus the use of multiple 
theories assisted the debate leading to convincing conclusions overall on the evolving use of purchasing portfolios. This suggests an inherent danger when selecting theories, i.e. that using one theory alone may introduce bias to the conclusions. This suggests the need to experiment with different theories, and indeed several authors have argued for the use of more than one theoretical lens (Carter \& Easton, 2011; Barratt et al. 2011). While this may be desirable, it is not always realistic within the context of a single paper. A key point here is that understanding theories can itself be a very complex task, and so the decision of some authors to develop in-depth expertise in one theory alone is acknowledged to be a good way to make a significant contribution to the literature. The key is to ensure that we recognise that a conclusion using a theory does not necessarily uncover 'truth' as such, it just provides one way of looking at the issues and hence one interpretation for managerial implications. This fits with the interpretivist research philosophy most appropriate to the qualitative end of the OM discipline. Thus it is concluded here that the particular choice of theories to use, or indeed the use of a 'pick n mix' approach, to add explanatory power should be acknowledged to be a limitation of scope of the paper. Further research will be needed to explore the sustainability phenomenon from alternative theoretical lenses, and this may further add to the existing findings, or indeed bring the existing findings into question. As all research has limitations, this is argued to be a justifiable limitation.

It is also important to consider how authors justify the choice of theory to use, and it noted that authors tend not to give detailed explanations for the choice of theories used, other than to simply state that the most relevant theories have been selected. For example, Carter \& Rogers (2008) claimed they chose four theories, as listed in Table VI that include the RBV and TCE, which give a unique yet complementary perspective; while Pagell et al. (2010) showed that RBV and TCE provide a conflicting perspective, as discussed above. In the latter paper, the reasons for choosing these two theories and then further adding stakeholder theory were not clearly stated. Given the lack of justification, investigation of a link between the topics studied and the theories chosen was undertaken, as shown in Table VI. However, it was concluded that this research field is too much in its infancy for any conclusions to be drawn from this analysis given that a variety of topics were often considered using the same theory. For example Belal (2002) and Ciliberti et al. (2008b) used stakeholder theory to focus on transparency issues only; while Pagell et al. (2010) and Vurro et al. (2009) were concerned with the nature of supply chain relationships, with both considering the relationships between a buyer and a supplier. Also, while it can be seen in Table VI that some theories are more popular than others, thus far this may be spurious rather than justifiable. It 
is thus concluded that so far, there is a lack of connection between the choice of topic and the choice of theory, and that authors do not tend to provide a clear explanation for the choice of theory, raising the question of whether some such justification should be offered in future research publications. This question is addressed in the concluding remarks to this section below.

\subsection{Summarising the Conclusions Regarding Research Question 2}

In conclusion, the first use of theory - theory dressing - is not a recommended use given that it appears not to add significantly to our understanding of the SRS phenomenon. The second use - theory matching - is a legitimate use for the justification of research rigour and thus aids in convincing the reader of the legitimacy of the conclusions, but again does not add much explanatory power in its own right. The third use - theory suggesting and explanation makes a stronger contribution as this: enables deductive research to be theory-driven, and hence can have a strong influence on the research findings and their interpretation; and/or contributes by strengthening the explanatory power associated with the research findings in inductive research. However, the most powerful means of contributing to our understanding of the SRS phenomenon is when theory is used in the fourth way identified above - theory expansion. That is when the theory itself is applied in a detailed manner, leading to new understanding of the phenomenon being studied and also to an expansion of the theory itself in the context of SRS. Figure 2 summarises these conclusions, showing that the depth of understanding of SRS increases as the depth of use of theory also increases.

$<$ Take in Figure 2>

Thus, in line with Schmenner et al. (2009), it is argued that theory is used most powerfully when it adds understanding to the phenomenon being studied. However, this discussion goes beyond that presented by Schmenner et al. (2009) as it provides a deeper understanding of how theory has been used effectively in research papers. It is also suggested here that when a topic is in its infancy, and much exploratory research is being undertaken, theory is not needed to justify a research publication as it is not essential to bring a contribution to our knowledge of an area. There are many examples of excellent papers that do not refer to a specific theoretical lens but which do make a significant contribution to our understanding of SRS (e.g. Maignon et al., 2002). However, as a research area becomes established, it is argued that an increasing number of theoretical lenses should emerge in the literature, each in turn adding to our depth of understanding. The justification for the choice of theoretical lens, or indeed a 'pick $n$ mix' approach to this choice, then can simply be that it has not been used 
before in a particular research context, and the justification for not using a theoretical lens at all can be simply that there is still much to be gained from descriptive insights derived through the undertaking of rigorous exploratory empirical research. In such cases, external validity must be found from other means than 'theory matching', such as through replication logic in multiple case studies (Voss, 2009). Where theory is used, researchers should ensure that it does not simply serve to reduce a set of rich findings to a series of platitudes, but that instead it brings real understanding that can lead to managerial implications of interest to practising managers. Within a discipline as practical as OM, it is argued here that all research should ultimately aim at informing managers and the education of future managers, and that hence theory is only useful if it takes us in this direction.

\section{Conclusion}

This review identified 157 articles that address Socially Responsible Sourcing (SRS), either as the main focus of the research or as part of an investigation into the broader TBL concept. It has identified the many different definitions used in the area in Table II and summarised the key components of socially responsible practice, from child labour through to respect for local democracies, through to animal welfare. In terms of definitions, a hierarchy of three terms have been proposed, with the key term used here, SRS, referring to the upstream supply chain and social issues only; while 'Sustainable Sourcing' incorporates environmental issues; and 'Sustainable SCM' also adds the downstream supply chain.

The 157 papers were classified according to their research perspective, context and method in Table III and into 8 research topic areas in Table V, with further details on key aspects of the studies provided in the Appendix. In answer to the first research question, the analysis indicates that much understanding has been gained into the strategic importance of SRS and the need for transparency; but much research is needed to understand how the latter can really be achieved in practice. This includes the need for proactive SRS strategies; more formal means of measuring sustainability; a better understanding of risk management in the context of SRS; more effective use of codes of conduct and sustainability standards; and further research into the inter-play between organisational culture and individual beliefs and values. All of the further research issues are particularly needed in the context of developing countries and from a supplier perspective, as the focus of research to date has tended to be from a buyer's perspective, where that buyer is located in a developed nation.

In terms of the use of theory, this review concludes that, in the existing SRS literature, a deeper application of theory has led to a deeper understanding of the sustainability 
phenomenon, as summarised in the typology presented in Figure 2. However, it is also concluded that theory is not an essential element of an insightful research paper, especially when a research topic is in its infancy. On the contrary, early exploratory empirical research can make a significant contribution, even if it is not theory-driven.

In summary, the contribution of this paper is to present a state-of-the-art literature review of SRS integrating the whole range of issues in the area. By conducting the first systematic literature review which focuses on SRS, our research serves as a good foundation for future researchers to develop the field further. The research gaps identified are specific to the management of social issues in upstream suppliers, enabling researchers in the OM \& SCM field to contribute more relevant and in-depth studies of this increasingly important management concern. From our critical and detailed analysis of the use of theory, it is proposed that an increased effective use of theory is needed as the field becomes more developed; and that at a minimum theory matching should be used to justify research rigour, while ideally theory suggesting/explaining and/or theory expansion should be used to aid in our understanding of the phenomenon being studied. However, it is acknowledged that these conclusions are drawn by looking at the SRS literature alone, and further analysis using different bodies of literature is needed in order to confidently generalise these findings to other fields of research.

Lastly, even though this paper's main focus is towards an academic and theoretical understanding of the SRS phenomena, the study has important managerial implications. Our thematic analysis can aid practitioners in understanding SRS from a wider perspective and the empirical studies referred to may help them gain insight into real-life opportunities, constraints and solutions. In particular, it highlights and summarises the key research findings to date including those listed below, and the appendix provides details of where papers on specific topics can be found for those who wish to read further:

- Strategies to ensure that SRS is embedded and integrated into their organisation; as well as some of the barriers and challenges that may be encountered when implementing these strategies;

- The importance of organisational and individual values in determining the SRS culture and practices, along with successful mechanisms used to date to ensure alignment between the two;

- Identification of formal tools to assess SRS risks; 
- The relative ineffectiveness of reporting as a transparency tool when compared to standards and codes of conduct, though the latter also have many inherent problems and issues to overcome;

- Early insights into the effect of SRS on financial performance and the tools that have been proposed to date to effectively measure SRS attainment.

Given that the review also shows that much of this research is in its infancy, it will also prevent managers from looking for research that has yet to be completed, and instead to apply pressure to the relevant bodies to support this important future research agenda.

\section{References}

Ageron, B., Gunasekaran, A. and Spalanzani, A. (2012), "Sustainable Supply Management: An Empirical Study", International Journal of Production Economics, Vol. 140 No. 1, pp. 168-182.

Amaeshi, K. M., Osuji, O. K. and Nnodim, P. (2008), "Corporate Social Responsibility in Supply Chains of Global Brands: A Boundaryless Responsibility? Clarifications, Exceptions and Implications", Journal of Business Ethics, Vol. 81 No. 1, pp. 223-234.

Andersen, M. and Skjoett-Larsen, T. (2009), "Corporate Social Responsibility in Global Supply Chains", Supply Chain Management, Vol. 14 No. 2, pp. 75-86.

Andrews, E., Lesage, P., Benoît, C., Parent, J., Norris, G. and Revéret, J. P. (2009), "Life Cycle Attribute Assessment: Case Study of Quebec Greenhouse Tomatoes", Journal of Industrial Ecology, Vol. 13 No. 4, pp. 565-578.

Awaysheh, A. and Klassen, R. D. (2010), "The Impact of Supply Chain Structure on the Use of Supplier Socially Responsible Practices", International Journal of Operations \& Production Management, Vol. 30 No. 12, pp. 1246-1268.

Baden, D., Harwood, I. A. and Woodward, D. G. (2011), "The Effects of Procurement Policies on 'Downstream'corporate Social Responsibility Activity", International Small Business Journal, Vol. 29 No. 3, pp. 259.

Baden, D. A., Harwood, I. A. and Woodward, D. G. (2009), "The Effect of Buyer Pressure on Suppliers in Smes to Demonstrate Csr Practices: An Added Incentive or Counter Productive?", European Management Journal, Vol. 27 No. 6, pp. 429-441.

Bai, C. and Sarkis, J. (2010), "Integrating Sustainability into Supplier Selection with Grey System and Rough Set Methodologies", International Journal of Production Economics, Vol. 124 No. 1, pp. 252-264.

Barratt M., Choi T.Y. and Mei L. (2011), "Qualitative case studies in operations management: Trends, research outcomes, and future research implications", Journal of Operations Management, Vol. 29, pp 329-342. 
Becker, W. S., Carbo, J. A. and Langella, I. M. (2010), "Beyond Self-Interest: Integrating Social Responsibility and Supply Chain Management with Human Resource Development", Human Resource Development Review, Vol. 9 No. 2, pp. 144-168.

Belal, A. R. (2002), "Stakeholder Accountability or Stakeholder Management: A Review of Uk Firms' Social and Ethical Accounting, Auditing and Reporting (Seaar) Practices", Corporate Social Responsibility and Environmental Management, Vol. 9 No. 1, pp. 8-25.

Beske, P., Koplin, J. and Seuring, S. (2008), "The Use of Environmental and Social Standards by German First-Tier Suppliers of the Volkswagen Ag", Corporate Social Responsibility and Environmental Management, Vol. 15 No. 2, pp. 63-75.

Birkin, F., Cashman, A., Koh, S. C. L. and Liu, Z. (2009), "New Sustainable Business Models in China", Business Strategy and the Environment, Vol. 18 No. 1, pp. 64-77.

Boyd, D. E., Spekman, R. E., Kamauff, J. W. and Werhane, P. (2007), "Corporate Social Responsibility in Global Supply Chains: A Procedural Justice Perspective", Long Range Planning, Vol. 40 No. 3, pp. 341-356.

Brammer, S. and Walker, H. (2011), "Sustainable Procurement in the Public Sector: An International Comparative Study", International Journal of Operations \& Production Management, Vol. 31 No. 4, pp. 452-476.

Burchielli, R., Delaney, A., Tate, J. and Coventry, K. (2009), "The Fairwear Campaign: An Ethical Network in the Australian Garment Industry", Journal of Business Ethics, Vol. 90 No. 4, pp. 575588.

Carbone, V., Moatti, V. and Vinzi, V. E. (2012), "Mapping Corporate Responsibility and Sustainable Supply Chains: An Exploratory Perspective", Business Strategy and the Environment, Vol. 21 No. 7, pp. 475-494.

Carter, C. R. (2000a), "Ethical Issues in International Buyer-Supplier Relationships: A Dyadic Examination", Journal of Operations Management, Vol. 18 No. 2, pp. 191-208.

Carter, C. R. (2000b), "Precursors of Unethical Behavior in Global Supplier Management", Journal of Supply Chain Management, Vol. 36 No. 1, pp. 45-56.

Carter, C. R. (2004), "Purchasing and Social Responsibility: A Replication and Extension", Journal of Supply Chain Management, Vol. 40 No. 4, pp. 4-16.

Carter, C. R. and Easton, P. L. (2011), "Sustainable Supply Chain Management: Evolution and Future Directions", International Journal of Physical Distribution \& Logistics Management, Vol. 41 No. 1, pp. 46-62.

Carter, C. R. and Jennings, M. M. (2002a), "Logistics Social Responsibility: An Integrative Framework", Journal of Business Logistics, Vol. 23 No. 1, pp. 145-180.

Carter, C. R. and Jennings, M. M. (2002b), "Social Responsibility and Supply Chain Relationships", Transportation Research. Part E, Logistics \& Transportation Review, Vol. 38 No. 1, pp. 37-52. 
Carter, C. R. and Jennings, M. M. (2004), "The Role of Purchasing in Corporate Social Responsibility: A Structural Equation Analysis", Journal of Business Logistics, Vol. 25 No. 1, pp. 145-186.

Carter, C. R. and Rogers, D. S. (2008), "A Framework of Sustainable Supply Chain Management: Moving toward New Theory", International Journal of Physical Distribution \& Logistics Management, Vol. 38 No. 5, pp. 360-387.

Castka, P. and Balzarova, M. A. (2008a), "Adoption of Social Responsibility through the Expansion of Existing Management Systems", Industrial Management + Data Systems, Vol. 108 No. 3, pp. 297-309.

Castka, P. and Balzarova, M. A. (2008b), "ISO 26000 and Supply Chains--on the Diffusion of the Social Responsibility Standard", International Journal of Production Economics, Vol. 111 No. 2, pp. 274-286.

Ciliberti, F., De Groot, G., De Haan, J. and Pontrandolfo, P. (2009), "Codes to Coordinate Supply Chains: SMEs' Experiences with Sa8000", Supply Chain Management: An International Journal, Vol. 14 No. 2, pp. 117-127.

Ciliberti, F., Pontrandolfo, P. and Scozzi, B. (2008a), "Investigating Corporate Social Responsibility in Supply Chains: A SME Perspective", Journal of Cleaner Production, Vol. 16 No. 15, pp. 15791588.

Ciliberti, F., Pontrandolfo, P. and Scozzi, B. (2008b), "Logistics Social Responsibility: Standard Adoption and Practices in Italian Companies", International Journal of Production Economics, Vol. 113 No. 1, pp. 88-106.

Collison, D. J., Cobb, G., Power, D. M. and Stevenson, L. A. (2008), "The Financial Performance of the Ftse4good Indices", Corporate Social Responsibility and Environmental Management, Vol. 15 No. 1, pp. 14-28.

Colwell, S. R., Zyphur, M. J. and Schminke, M. (2011), "When Does Ethical Code Enforcement Matter in the Inter-Organizational Context? The Moderating Role of Switching Costs", Journal of Business Ethics, Vol. 104 No. 1, pp. 47-58.

Cooper, R. W., Frank, G. L. and Kemp, R. A. (1997), "Ethical Issues, Helps and Challenges Perceptions of Members of the Chartered Institute of Purchasing and Supply", European Journal of Purchasing \& Supply Management, Vol. 3 No. 4, pp. 189-198.

Cooper, R. W., Frank, G. L. and Kemp, R. A. (2000), "A Multinational Comparison of Key Ethical Issues, Helps and Challenges in the Purchasing and Supply Management Profession: The Key Implications for Business and the Professions", Journal of Business Ethics, Vol. No. pp. 83-100.

Crespin-Mazet, F. and Dontenwill, E. (2012), "Sustainable Procurement: Building Legitimacy in the Supply Network", Journal of Purchasing and Supply Management, Vol. 18 No. 4, pp. 207-217.

De Bakker, F. and Nijhof, A. (2002), "Responsible Chain Management: A Capability Assessment Framework", Business Strategy and the Environment, Vol. 11 No. 1, pp. 63-75. 
De Brito, M. P., Carbone, V. and Blanquart, C. M. (2008), "Towards a Sustainable Fashion Retail Supply Chain in Europe: Organisation and Performance", International Journal of Production Economics, Vol. 114 No. 2, pp. 534-553.

Denyer, D. and Tranfield, D. (2009), "Chapter 39: Producing a Systematic Review”, pp. 671-689, The Sage Handbook of Organizational Research Methods, Editors Buchanan, D. and Bryman, A., Sage Publications Ltd, London. ISBN:978-1-4129-3118-2.

Eadie, R., Mckeown, C. and Anderson, K. (2011), "The Social Element of Sustainable Civil Engineering Public Procurement in Northern Ireland", International Journal of Business and Social Science, Vol. 2 No. 12, pp. 36-43.

Ehrgott, M., Reimann, F., Kaufmann, L. and Carter, C. R. (2011), "Social Sustainability in Selecting Emerging Economy Suppliers", Journal of Business Ethics, Vol. 98 No. 1, pp. 99-119.

Elkington, J. (1998), "Partnerships from Cannibals with Forks: The Triple Bottom Line of 21st Century Business", Environmental Quality Management, Vol. 8 No. 1, pp. 37-51.

Eltantawy, R. A., Fox, G. L. and Giunipero, L. (2009), "Supply Management Ethical Responsibility: Reputation and Performance Impacts", Supply Chain Management, Vol. 14 No. 2, pp. 99-108.

Erridge, A. and Hennigan, S. (2012), "Sustainable Procurement in Health and Social Care in Northern Ireland", Public Money \& Management, Vol. 32 No. 5, pp. 363-370.

Fassin, Y. (2008), "SMEs and the Fallacy of Formalising Csr", Business Ethics: A European Review, Vol. 17 No. 4, pp. 364-378.

Font, X., Tapper, R., Schwartz, K. and Kornilaki, M. (2008), "Sustainable Supply Chain Management in Tourism", Business Strategy and the Environment, Vol. 17 No. 4, pp. 260-271.

Forsman-Hugg, S., Katajajuuri, J.-M., Riipi, I., Mäkelä, J., Järvelä, K. and Timonen, P. (2013), "Key Csr Dimensions for the Food Chain", British Food Journal, Vol. 115 No. 1, pp. 30-47.

Fukukawa, K. and Teramoto, Y. (2009), "Understanding Japanese Csr: The Reflections of Managers in the Field of Global Operations", Journal of Business Ethics, Vol. 85 No. pp. 133-146.

Gimenez, C., Sierra, V. and Rodon, J. (2012), "Sustainable Operations: Their Impact on the Triple Bottom Line", International Journal of Production Economics, Vol. 140 No. 1, pp. 149-159.

Gimenez, C. and Tachizawa, E. M. (2012), "Extending Sustainability to Suppliers: A Systematic Literature Review", Supply Chain Management: An International Journal, Vol. 17 No. 5, pp. 531543.

Goebel, P., Reuter, C., Pibernik, R. and Sichtmann, C. (2012), "The Influence of Ethical Culture on Supplier Selection in the Context of Sustainable Sourcing", International Journal of Production Economics, Vol. 140 No. 1, pp. 7-17.

Gopalakrishnan, K., Yusuf, Y. Y., Musa, A., Abubakar, T. and Ambursa, H. M. (2012), "Sustainable Supply Chain Management: A Case Study of British Aerospace (Bae) Systems", International Journal of Production Economics, Vol. 140 No. 1, pp. 193-203. 
Graafland, J. J. (2002), "Sourcing Ethics in the Textile Sector: The Case of C\&A", Business Ethics: A European Review, Vol. 11 No. 3, pp. 282-294.

Gugler, P. and Shi, J. (2009), "Corporate Social Responsibility for Developing Country Multinational Corporations: Lost War in Pertaining Global Competitiveness?", Journal of Business Ethics, Vol. 87 No. 1, pp. 3-24.

Hall, J. and Matos, S. (2010), "Incorporating Impoverished Communities in Sustainable Supply Chains", International Journal of Physical Distribution \& Logistics Management, Vol. 40 No. 1/2, pp. 124-147.

Hall, J., Matos, S. and Silvestre, B. (2012), "Understanding Why Firms Should Invest in Sustainable Supply Chains: A Complexity Approach", International journal of production research, Vol. 50 No. 5, pp. 1332.

Harwood, I. and Humby, S. (2008), "Embedding Corporate Responsibility into Supply: A Snapshot of Progress", European Management Journal, Vol. 26 No. 3, pp. 166-174.

Harwood, I., Humby, S. and Harwood, A. (2011), "On the Resilience of Corporate Social Responsibility", European Management Journal, Vol. 29 No. 4, pp. 283-290.

Hoejmose, S. U. and Adrien-Kirby, A. J. (2012), "Socially and Environmentally Responsible Procurement: A Literature Review and Future Research Agenda of a Managerial Issue in the 21st Century", Journal of Purchasing and Supply Management, Vol. 18 No. 4, pp. 232-242.

Hoejmose, S., Brammer, S. and Millington, A. (2013), "An Empirical Examination of the Relationship between Business Strategy and Socially Responsible Supply Chain Management", International Journal of Operations \& Production Management, Vol. 33 No. 5, pp. 589-621.

Hollos, D., Blome, C. and Foerstl, K. (2011), "Does Sustainable Supplier Co-Operation Affect Performance? Examining Implications for the Triple Bottom Line", International journal of production research, Vol. 50 No. 11, pp. 2968-2986.

Holt, D. (2004), "Managing the Interface between Suppliers and Organizations for Environmental Responsibility-an Exploration of Current Practices in the Uk", Corporate Social Responsibility and Environmental Management, Vol. 11 No. 2, pp. 71-84.

Hutchins, M. J. and Sutherland, J. W. (2008), "An Exploration of Measures of Social Sustainability and Their Application to Supply Chain Decisions", Journal of Cleaner Production, Vol. 16 No. 15, pp. 1688-1698.

Illge, L. and Preuss, L. (2012), "Strategies for Sustainable Cotton: Comparing Niche with Mainstream Markets", Corporate Social Responsibility and Environmental Management, Vol. 19 No. 2, pp. 102-113.

Isaksson, R., Johansson, P., and Fischer, K., 2010, Detecting supply chain innovation potential for sustainable development, Journal of Business Ethics, Vol. 97, No. 3, pp.425-442. 
Jiang, B. (2009a), "The Effects of Interorganizational Governance on Supplier's Compliance with Scc: An Empirical Examination of Compliant and Non-Compliant Suppliers", Journal of Operations Management, Vol. 27 No. 4, pp. 267-280.

Jiang, B. (2009b), "Implementing Supplier Codes of Conduct in Global Supply Chains: Process Explanations from Theoretic and Empirical Perspectives", Journal of Business Ethics, Vol. 85 No. 1, pp. 77-92.

Joo, S.-J., Min, H., Kwon, I.-W. G. and Kwon, H. (2010), "Comparative Efficiencies of Specialty Coffee Retailers from the Perspectives of Socially Responsible Global Sourcing", International Journal of Logistics Management, The, Vol. 21 No. 3, pp. 490-509.

Jorgensen, A. L. and Knudsen, J. S. (2006), "Sustainable Competitiveness in Global Value Chains: How Do Small Danish Firms Behave?", Corporate Governance, Vol. 6 No. 4, pp. 449-462.

Kaptein, M. (2004), "Business Codes of Multinational Firms: What Do They Say?", Journal of Business Ethics, Vol. 50 No. 1, pp. 13-31.

Keating, B., Quazi, A., Kriz, A. and Coltman, T. (2008), "In Pursuit of a Sustainable Supply Chain: Insights from Westpac Banking Corporation", Supply Chain Management, Vol. 13 No. 3, pp. 175179.

Ketola, T. (2010), "Five Leaps to Corporate Sustainability through a Corporate Responsibility Portfolio Matrix", Corporate Social Responsibility and Environmental Management, Vol. 17 No. 6, pp. 320-336.

Klassen, R. D. and Vereecke, A. (2012), "Social Issues in Supply Chains: Capabilities Link Responsibility, Risk (Opportunity), and Performance", International Journal of Production Economics, Vol. 140 No. 1, pp. 103-115.

Kleindorfer, P. R., Singhal, K. and Van Wassenhove, L. N. (2005), "Sustainable Operations Management", Production and operations management, Vol. 14 No. 4, pp. 482-492.

Kogg, B. and Mont, O. (2012), "Environmental and Social Responsibility in Supply Chains: The Practise of Choice and Inter-Organisational Management", Ecological economics, Vol. 83 No. 2012, pp. 154-163.

Kolk, A. (2012), "Towards a Sustainable Coffee Market: Paradoxes Faced by a Multinational Company", Corporate Social Responsibility and Environmental Management, Vol. 19 No. 2, pp. 79-89.

Kolk, A. and van Tulder, R. (2002a), "Child Labor and Multinational Conduct: A Comparison of International Business and Stakeholder Codes", Journal of Business Ethics, Vol. 36 No. 3, pp. 291-301.

Kolk, A. and van Tulder, R. (2002b), "The Effectiveness of Self-Regulation:: Corporate Codes of Conduct and Child Labour", European Management Journal, Vol. 20 No. 3, pp. 260-271.

Kolk, A. and van Tulder, R. (2004), "Ethics in International Business: Multinational Approaches to Child Labor", Journal of World Business, Vol. 39 No. 1, pp. 49-60. 
Koplin, J., Seuring, S. and Mesterharm, M. (2007), "Incorporating Sustainability into Supply Management in the Automotive Industry-the Case of the Volkswagen Ag", Journal of Cleaner Production, Vol. 15 No. 11, pp. 1053-1062.

Kortelainen, K. (2008), "Global Supply Chains and Social Requirements: Case Studies of Labour Condition Auditing in the People's Republic of China", Business Strategy and the Environment, Vol. 17 No. 7, pp. 431-443.

Krause, D. R., Vachon, S. and Klassen, R. D. (2009), "Special Topic Forum on Sustainable Supply Chain Management: Introduction and Reflections on the Role of Purchasing Management*", Journal of Supply Chain Management, Vol. 45 No. 4, pp. 18-25.

Krueger, D. A. (2008), "The Ethics of Global Supply Chains in China-Convergences of East and West", Journal of Business Ethics, Vol. 79 No. 1-2, pp. 113-120.

Kudla, N. L. and Klaas-Wissing, T. (2012), "Sustainability in Shipper-Logistics Service Provider Relationships: A Tentative Taxonomy Based on Agency Theory and Stimulus-Response Analysis", Journal of Purchasing and Supply Management, Vol. 18 No. 4, pp. 218-231.

Lamberti, L. and Lettieri, E. (2009), "Csr Practices and Corporate Strategy: Evidence from a Longitudinal Case Study", Journal of Business Ethics, Vol. 87 No. 2, pp. 153-168.

Lee, K-H and Kim, J-W. (2009), "Current Status of Csr in the Realm of Supply Management: The Case of the Korean Electronics Industry", Supply Chain Management: An International Journal, Vol. 14 No. 2, pp. 138-148.

Lehtinen, U. (2012), "Sustainability and Local Food Procurement: A Case Study of Finnish Public Catering", British Food Journal, Vol. 114 No. 8, pp. 1053-1071.

Leire, C. and Mont, O. (2010), "The Implementation of Socially Responsible Purchasing", Corporate Social Responsibility and Environmental Management, Vol. 17 No. 1, pp. 27-39.

Lillywhite, S. (2007), "Ethical Purchasing and Workers' Rights in China: The Case of the Brotherhood of St Laurence", The Journal of Industrial Relations, Vol. 49 No. 5, pp. 687.

Lim, S. J. and Phillips, J. (2008), "Embedding Csr Values: The Global Footwear Industry's Evolving Governance Structure", Journal of Business Ethics, Vol. 81 No. 1, pp. 143-156.

Lozano, R. and Huisingh, D. (2011), "Inter-Linking Issues and Dimensions in Sustainability Reporting", Journal of Cleaner Production, Vol. 19 No. 2-3, pp. 99-107.

Luken, R. and Stares, R. (2005), "Small Business Responsibility in Developing Countries: A Threat or an Opportunity?", Business Strategy and the Environment, Vol. 14 No. 1, pp. 38-53.

MacCarthy, B. L. and Jayarathne, P. G. S. A. (2012), "Sustainable Collaborative Supply Networks in the International Clothing Industry: A Comparative Analysis of Two Retailers", Production Planning \& Control, Vol. 23 No. 4, pp. 252-268.

Maignan, I., Hillebrand, B. and Mcalister, D. (2002), "Managing Socially-Responsible Buying:: How to Integrate Non-Economic Criteria into the Purchasing Process", European Management Journal, Vol. 20 No. 6, pp. 641-648. 
Maloni, M. J. and Brown, M. E. (2006), "Corporate Social Responsibility in the Supply Chain: An Application in the Food Industry", Journal of Business Ethics, Vol. 68 No. 1, pp. 35-52.

Mamic, I. (2005), "Managing Global Supply Chain: The Sports Footwear, Apparel and Retail Sectors", Journal of Business Ethics, Vol. 59 No. 1, pp. 81-100.

Manning, L. (2013), "Corporate and Consumer Social Responsibility in the Food Supply Chain", British Food Journal, Vol. 115 No. 1, pp. 9-29.

Manning, L., Baines, R. and Chadd, S. (2006), "Ethical Modelling of the Food Supply Chain", British Food Journal, Vol. 108 No. 5, pp. 358-370.

Markley, M. J. and Davis, L. (2007), "Exploring Future Competitive Advantage through Sustainable Supply Chains", International Journal of Physical Distribution \& Logistics Management, Vol. 37 No. 9, pp. 763-774.

Meehan, J. and Bryde, D. (2011), "Sustainable Procurement Practice", Business Strategy and the Environment, Vol. 20 No. 2, pp. 94-106.

Mueller, M., Dos Santos, V. G. and Seuring, S. (2009), "The Contribution of Environmental and Social Standards Towards Ensuring Legitimacy in Supply Chain Governance", Journal of Business Ethics, Vol. 89 No. 4, pp. 509-523.

New, S. J. (1997), "The Scope of Supply Chain Management Research", Supply Chain Management: An International Journal, Vol. 2 No. 1, pp. 15-22.

Nikoloyuk, J., Burns, T. R. and Man, R. D. (2010), "The Promise and Limitations of Partnered Governance: The Case of Sustainable Palm Oil", Corporate Governance, Vol. 10 No. 1, pp. 59-72.

Ntayi, J. M., Ngoboka, P. and Kakooza, C. S. (2013), "Moral Schemas and Corruption in Ugandan Public Procurement", Journal of Business Ethics, Vol. 112 No. 3, pp. 417-436.

Oruezabalaa, G. and Rico, J.-C. (2012), "The Impact of Sustainable Public Procurement on Supplier Management - the Case of French Public Hospitals", Industrial Marketing Management, Vol. 41 No. 4, pp. 573-580.

Pagell, M. and Wu, Z. (2009), "Building a More Complete Theory of Sustainable Supply Chain Management Using Case Studies of 10 Exemplars", Journal of Supply Chain Management, Vol. 45 No. 2, pp. 37-56.

Pagell, M., Wu, Z. and Wasserman, M. E. (2010), "Thinking Differently About Purchasing Portfolios: An Assessment of Sustainable Sourcing", Journal of Supply Chain Management, Vol. 46 No. 1, pp. 57-73.

Panapanaan, V. M., Linnanen, L., Karvonen, M.-M. and Phan, V. T. (2003), "Roadmapping Corporate Social Responsibility in Finnish Companies", Journal of Business Ethics, Vol. 44 No. 2/3, pp. 133-148.

Park, H. (2005), "The Role of Idealism and Relativism as Dispositional Characteristics in the Socially Responsible Decision-Making Process", Journal of Business Ethics, Vol. 56 No. 1, pp. 81-98. 
Park-Poaps, H. and Rees, K. (2010), "Stakeholder Forces of Socially Responsible Supply Chain Management Orientation", Journal of Business Ethics, Vol. 92 No. 2, pp. 305-322.

Pedersen, E. (2009), "The Many and the Few: Rounding up the SMEs That Manage Csr in the Supply Chain", Supply Chain Management, Vol. 14 No. 2, pp. 109-116.

Perez-Aleman, P. and Sandilands, M. (2008), "Building Value at the Top and the Bottom of the Global Supply Chain: Mnc-Ngo Partnerships", California management review, Vol. 51 No. 1, pp. 24-49.

Polonsky, M. and Jevons, C. (2009), "Global Branding and Strategic Csr: An Overview of Three Types of Complexity", International Marketing Review, Vol. 26 No. 3, pp. 327-347.

Pretious, M. and Love, M. (2006), "Sourcing Ethics and the Global Market: The Case of the Uk Retail Clothing Sector", International Journal of Retail \& Distribution Management, Vol. 34 No. 12, pp. 892-903.

Preuss, L. (2007), "Buying into Our Future: Sustainability Initiatives in Local Government Procurement", Business Strategy and the Environment, Vol. 16 No. 5, pp. 354-365.

Preuss, L. (2009a), "Addressing Sustainable Development through Public Procurement: The Case of Local Government", Supply Chain Management: An International Journal, Vol. 14 No. 3, pp. 213 223.

Preuss, L. (2009b), "Ethical Sourcing Codes of Large Uk-Based Corporations: Prevalence, Content, Limitations", Journal of Business Ethics, Vol. 88 No. 4, pp. 735-747.

Preuss, L. and Walker, H. (2011), "Psychological Barriers in the Road to Sustainable Development: Evidence from Public Sector Procurement", Public Administration, Vol. 89 No. 2, pp. 493-521.

Prieto-Carrón, M. (2008), "Women Workers, Industrialization, Global Supply Chains and Corporate Codes of Conduct", Journal of Business Ethics, Vol. 83 No. 1, pp. 5-17.

Pullman, M. E. and Dillard, J. (2010), "Values Based Supply Chain Management and Emergent Organizational Structures", International Journal of Operations \& Production Management, Vol. 30 No. 7, pp. 744-771.

Reuter, C., Foerstl, K., Hartmann, E. and Blome, C. (2010), "Sustainable Global Supplier Management: The Role of Dynamic Capabilities in Achieving Competitive Advantage", Journal of Supply Chain Management, Vol. 46 No. 2, pp. 45-63.

Reuter, C., Goebel, P. and Foerstl, K. (2012), "The Impact of Stakeholder Orientation on Sustainability and Cost Prevalence in Supplier Selection Decisions", Journal of Purchasing and Supply Management, Vol. 18 No. 4, pp. 270-281.

Rimmington, M., Smith, J. C. and Hawkins, R. (2006), "Corporate Social Responsibility and Sustainable Food Procurement", British Food Journal, Vol. 108 No. 10, pp. 824-837.

Roberts, S. (2003), "Supply Chain Specific? Understanding the Patchy Success of Ethical Sourcing Initiatives", Journal of Business Ethics, Vol. 44 No. 2-3, pp. 159-170. 
Robinson, P. K. (2010), "Responsible Retailing: The Practice of Csr in Banana Plantations in Costa Rica", Journal of Business Ethics, Vol. 91 No. pp. 279-289.

Sarkis, J., Helms, M. M. and Hervani, A. A. (2010), "Reverse Logistics and Social Sustainability", Corporate Social - Responsibility and Environmental Management, Vol. 17 No. 6, pp. 337-354.

Sarkis, J., Zhu, Q. and Lai, K. (2011), "An Organizational Theoretic Review of Green Supply Chain Management Literature", International Journal of Production Economics, Vol. 130 No. 1, pp. 115.

Schmenner R.W., Van Wassenhove L., Ketokivi M., Heyl J. And Lusch R.F. (2009), "Too much theory, not enough understanding", Journal of Operations Management, Vol. 27, pp 339-343.

Schneider, L. and Wallenburg, C. M. (2012), "Implementing Sustainable Sourcing-Does Purchasing Need to Change?", Journal of Purchasing and Supply Management, Vol. 18 No. 4, pp. 243-257.

Seuring, S. and Müller, M. (2008a), "Core Issues in Sustainable Supply Chain Management-a Delphi Study", Business Strategy and the Environment, Vol. 17 No. 8, pp. 455-466.

Seuring, S. and Müller, M. (2008b), "From a Literature Review to a Conceptual Framework for Sustainable Supply Chain Management", Journal of Cleaner Production, Vol. 16 No. 15, pp. 1699-1710.

Sobczak, A. (2003), "Codes of Conduct in Subcontracting Networks: A Labour Law Perspective", Journal of Business Ethics, Vol. 44 No. 2/3, pp. 225-234.

Spekman, R. E. and Davis, E. W. (2004), "Risky Business: Expanding the Discussion on Risk and the Extended Enterprise", International Journal of Physical Distribution \& Logistics Management, Vol. 34 No. 5, pp. 414-433.

Spence, L. and Bourlakis, M. (2009), "The Evolution from Corporate Social Responsibility to Supply Chain Responsibility: The Case of Waitrose", Supply Chain Management: An International Journal, Vol. 14 No. 4, pp. 291-302.

Stigzelius, I. and Mark-Herbert, C. (2009), "Tailoring Corporate Responsibility to Suppliers: Managing Sa8000 in Indian Garment Manufacturing", Scandinavian Journal of Management, Vol. 25 No. 1, pp. 46-56.

Strand, R. (2009), "Corporate Responsibility in Scandinavian Supply Chains", Journal of Business Ethics, Vol. 85 No. 1, pp. 179-185.

Svensson, G. (2009), "The Transparency of Scm Ethics: Conceptual Framework and Empirical Illustrations", Supply Chain Management: An International Journal, Vol. 14 No. 4, pp. 259-269.

Svensson, G. and Wagner, B. (2012), "Implementation of a Sustainable Business Cycle: The Case of a Swedish Dairy Producer", Supply Chain Management: An International Journal, Vol. 17 No. 1, pp. 93-97.

Taplin, J. R. D., Bent, D. and Aeron-Thomas, D. (2006), "Developing a Sustainability Accounting Framework to Inform Strategic Business Decisions: A Case Study from the Chemicals Industry", Business Strategy and the Environment, Vol. 15 No. 5, pp. 347-360. 
Tate, W. L., Ellram, L. M. and Kirchoff, J. O. N. F. (2010), "Corporate Social Responsibility Reports:

A Thematic Analysis Related to Supply Chain Management", Journal of Supply Chain Management, Vol. 46 No. 1, pp. 19-44.

Tencati, A., Quaglia, V. and Russo, A. (2008), "Unintended Consequences of Csr: Protectionism and Collateral Damage in Global Supply Chains: The Case of Vietnam", Corporate Governance, Vol. 8 No. 4 , pp. 518-531.

Teuscher, P., Grüninger, B. and Ferdinand, N. (2006), "Risk Management in Sustainable Supply Chain Management (SSCM): Lessons Learnt from the Case of Gmo-Free Soybeans", Corporate Social Responsibility and Environmental Management, Vol. 13 No. 1, pp. 1-10.

Tranfield, D., Denyer, D. and Smart, P. (2003), "Towards a Methodology for Developing EvidenceInformed Management Knowledge by Means of Systematic Review", British Journal of Management, Vol. 14 No. 3, pp. 207-222.

Tsoi, J. (2010), "Stakeholders' Perceptions and Future Scenarios to Improve Corporate Social Responsibility in Hong Kong and Mainland China", Journal of Business Ethics, Vol. 91 No. 3, pp. 391-404.

van Tulder, R. V. and Kolk, A. (2001), "Multinationality and Corporate Ethics: Codes of Conduct in the Sporting Goods Industry", Journal of International Business Studies, Vol. 32 No. 2, pp. $267-$ 283.

van Tulder, R. V., Wijk, J. V. and Kolk, A. (2009), "From Chain Liability to Chain Responsibility: Mne Approaches to Implement Safety and Health Codes in International Supply Chains", Journal of Business Ethics, Vol. 85 No. 2, pp. 399-412.

van Hoek, R. and Johnson, M. (2010), "Sustainability and Energy Efficiency: Research Implications from an Academic Roundtable and Two Case Examples", International Journal of Physical Distribution \& Logistics Management, Vol. 40 No. 1/2, pp. 148-158.

Vasileiou, K. and Morris, J. (2006), "The Sustainability of the Supply Chain for Fresh Potatoes in Britain", Supply Chain Management: An International Journal, Vol. 11 No. 4, pp. 317-327.

Voss, C. (2009), "Case Research in Operations Management", in Karlsson, C. (Ed.), Researching Operations Management, Routledge: New York.

Vurro, C., Russo, A. and Perrini, F. (2009), "Shaping Sustainable Value Chains: Network Determinants of Supply Chain Governance Models", Journal of Business Ethics, Vol. 90 No. 4, pp. 607-621.

Walker, H. and Brammer, S. (2009), "Sustainable Procurement in the United Kingdom Public Sector", Supply Chain Management: An International Journal, Vol. 14 No. 2, pp. 128-137.

Walker, H. and Brammer, S. (2012), "The Relationship between Sustainable Procurement and EProcurement in the Public Sector", International Journal of Production Economics, Vol. 140 No. 1, pp. 256-268. 
Walker, H. and Jones, N. (2012), "Sustainable Supply Chain Management across the Uk Private Sector", Supply Chain Management: An International Journal, Vol. 17 No. 1, pp. 15-28.

Walker, H. and Preuss, L. (2008), "Fostering Sustainability through Sourcing from Small Businesses:

Public Sector Perspectives", Journal of Cleaner Production, Vol. 16 No. 15, pp. 1600-1609.

Wang, Z. and Sarkis, J. (2013), "The Relationship of Sustainable Supply Chain Management with Corporate Financial Performance", International Journal of Productivity and Performance Management, Vol. 62 No. 8, pp. 871 - 888.

Welford, R. and Frost, S. (2006), "Corporate Social Responsibility in Asian Supply Chains", Corporate Social Responsibility and Environmental Management, Vol. 13 No. 3, pp. 166-176.

Wiese, A. and Toporowski, W. (2013), "Csr Failures in Food Supply Chains-an Agency Perspective", British Food Journal, Vol. 115 No. 1, pp. 92-107.

Wild, N. and Zhou, L. (2011), "Ethical Procurement Strategies for International Aid Non-Government Organisations", Supply Chain Management: An International Journal, Vol. 16 No. 2, pp. 110-127. Winstanley, D., Clark, J. and Leeson, H. (2002), "Approaches to Child Labour in the Supply Chain", Business Ethics: A European Review, Vol. 11 No. 3, pp. 210-223.

Winter, M. and Knemeyer, A. M. (2013), "Exploring the Integration of Sustainability and Supply Chain Management: Current State and Opportunities for Future Inquiry", International Journal of Physical Distribution \& Logistics Management, Vol. 43 No. 1, pp. 18-38.

Wittstruck, D. and Teuteberg, F. (2012), "Understanding the Success Factors of Sustainable Supply Chain Management: Empirical Evidence from the Electrics and Electronics Industry", Corporate Social Responsibility and Environmental Management, Vol. 19 No. 3, pp. 141-158.

Worthington, I. (2009), "Corporate Perceptions of the Business Case for Supplier Diversity: How Socially Responsible Purchasing Can 'Pay'", Journal of Business Ethics, Vol. 90 No. 1, pp. 47-60.

Wu, Z. and Pagell, M. (2011), "Balancing Priorities: Decision-Making in Sustainable Supply Chain Management", Journal of Operations Management, Vol. 29 No. 6, pp. 577-590.

Yakovleva, N., Sarkis, J. and Sloan, T. (2011), "Sustainable Benchmarking of Supply Chains: The Case of the Food Industry", International journal of production research, Vol. 50 No. 5, pp. 12971317.

Yu, X. (2008), "Impacts of Corporate Code of Conduct on Labor Standards: A Case Study of Reebok's Athletic Footwear Supplier Factory in China", Journal of Business Ethics, Vol. 81 No. 3, pp. 513-529.

Zailani, S., Jeyaraman, K., Vengadasan, G. and Premkumar, R. (2012), "Sustainable Supply Chain Management (Sscm) in Malaysia: A Survey", International Journal of Production Economics, Vol. No. pp.

Zahra, S. A. and George, G. (2002), "Absorptive capacity: a review, re-conceptualization, and extension", Academy of Management Review, Vol. 27 No. 2, pp. 85-203. 
Zsidisin, G. A. and Siferd, S. P. (2001), "Environmental Purchasing: A Framework for Theory Development", European Journal of Purchasing \& Supply Management, Vol. 7 No. 1, pp. 61-73. 
Table I -Journals where the Selected Papers have been Published

\begin{tabular}{|c|c|c|c|c|c|}
\hline Journal & $\begin{array}{l}\text { N. of } \\
\text { Articles }\end{array}$ & $\begin{array}{l}1997- \\
2001\end{array}$ & $2002-$ & $\begin{array}{l}2006- \\
2009\end{array}$ & $\begin{array}{l}2010- \\
\text { April } \\
2013 \\
\end{array}$ \\
\hline Journal of Business Ethics & 32 & 1 & 7 & 18 & 6 \\
\hline $\begin{array}{l}\text { Supply Chain Management: an International } \\
\text { Journal }\end{array}$ & 16 & 1 & & 11 & 4 \\
\hline $\begin{array}{l}\text { Corporate Social Responsibility and } \\
\text { Environmental Management }\end{array}$ & 12 & & 2 & 4 & 6 \\
\hline $\begin{array}{l}\text { International Journal of Production } \\
\text { Economics }\end{array}$ & 11 & & & 3 & 8 \\
\hline Business Strategy \& the Environment & 10 & & 2 & 6 & 2 \\
\hline $\begin{array}{l}\text { International Journal of Physical Distribution } \\
\text { \& Logistics Management }\end{array}$ & 7 & & 1 & 2 & 4 \\
\hline Journal of Supply Chain Management & 7 & 1 & 1 & 2 & 3 \\
\hline British Food Journal & 6 & & & 2 & 4 \\
\hline Journal of Cleaner Production & 6 & & & 5 & 1 \\
\hline European Management Journal & 5 & & 2 & 2 & 1 \\
\hline $\begin{array}{l}\text { Journal of Purchasing and Supply } \\
\text { Management }\end{array}$ & 5 & & & & 5 \\
\hline $\begin{array}{l}\text { International Journal of Operations and } \\
\text { Production Management }\end{array}$ & 3 & & & & 3 \\
\hline International Journal of Production Research & 3 & & & & 3 \\
\hline Business Ethics: A European Review & 3 & & 2 & 1 & \\
\hline Corporate Governance & 3 & & & 2 & 1 \\
\hline Journal of Operations Management & 3 & 1 & & 1 & 1 \\
\hline Journal of Business Logistics & 2 & & 2 & & \\
\hline California Management Review & 1 & & & 1 & \\
\hline Ecological Economics & 1 & & & & 1 \\
\hline $\begin{array}{l}\text { European Journal of Purchasing \& Supply } \\
\text { Management }\end{array}$ & 1 & 1 & & & \\
\hline Human Resource Development Review & 1 & & & & 1 \\
\hline Industrial Management \& Data Systems & 1 & & & 1 & \\
\hline Industrial Marketing Management & 1 & & & & 1 \\
\hline International Marketing Review & 1 & & & 1 & \\
\hline $\begin{array}{l}\text { International Journal of Business and Social } \\
\text { Science }\end{array}$ & 1 & & & & 1 \\
\hline $\begin{array}{l}\text { International Journal of Logistics } \\
\text { Management }\end{array}$ & 1 & & & & 1 \\
\hline $\begin{array}{l}\text { International Journal of Productivity and } \\
\text { Performance Management }\end{array}$ & 1 & & & & 1 \\
\hline $\begin{array}{l}\text { International Journal of Retail \& Distribution } \\
\text { Management }\end{array}$ & 1 & & & 1 & \\
\hline International Small Business Journal & 1 & & & & 1 \\
\hline Journal of Industrial Ecology & 1 & & & 1 & \\
\hline Journal of International Business Studies & 1 & 1 & & & \\
\hline Journal of World Business & 1 & & 1 & & \\
\hline Long Range Planning & 1 & & & 1 & \\
\hline Production Planning \& Control & 1 & & & & 1 \\
\hline Production \& Operations Management & 1 & & 1 & & \\
\hline Public Administration & 1 & & & & 1 \\
\hline Public Money \& Management & 1 & & & & 1 \\
\hline Scandinavian Journal of Management & 1 & & & 1 & \\
\hline The Journal of Industrial Relations & 1 & & & 1 & \\
\hline $\begin{array}{l}\text { Transportation Research. Part E, Logistics \& } \\
\text { Transportation Review }\end{array}$ & 1 & & 1 & & \\
\hline Total & 157 & 6 & 22 & 67 & 62 \\
\hline
\end{tabular}


Table II - Terminology Identified in the Literature

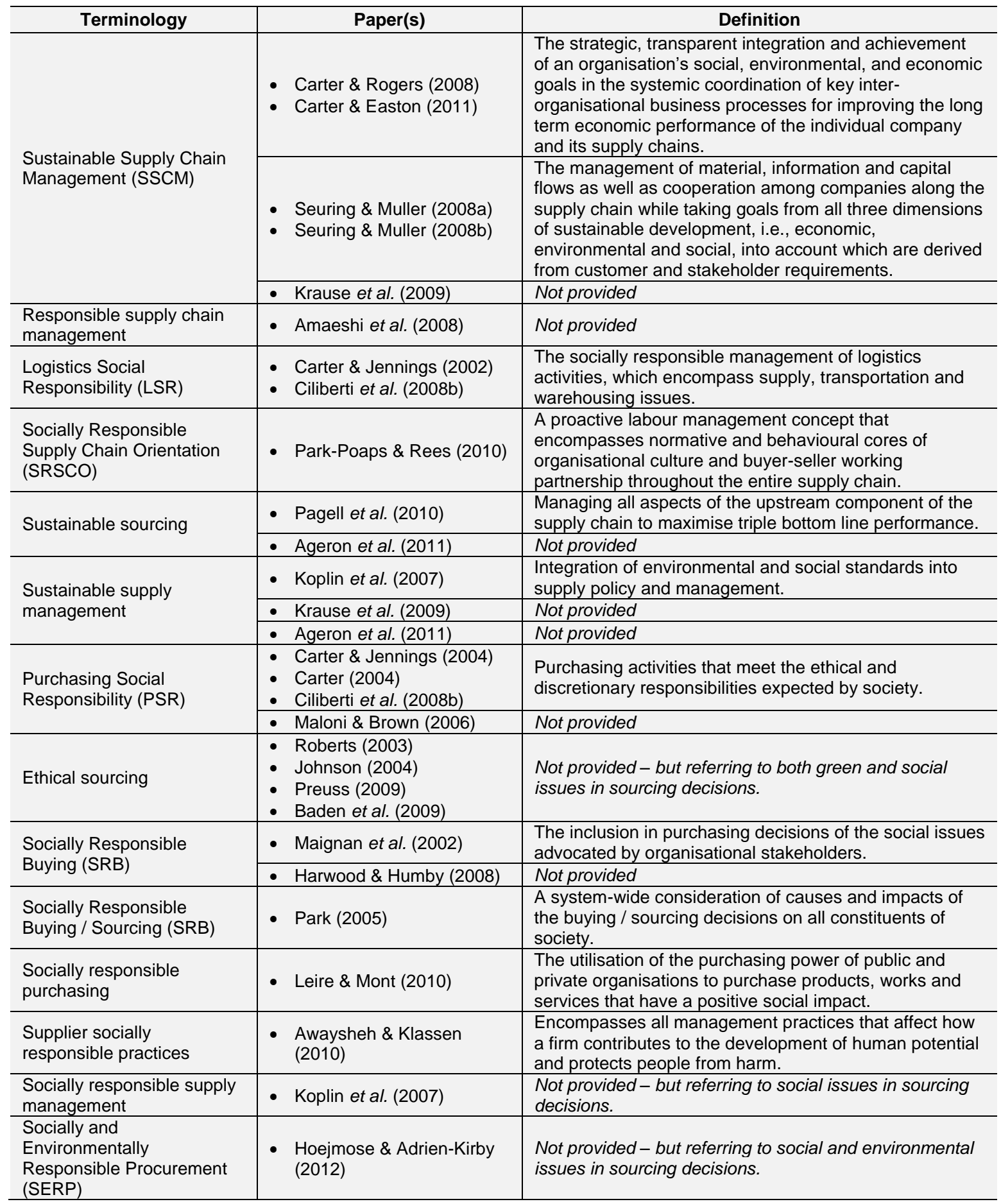


Table III - Classification of Reviewed Papers (Research Method, Use of Theory, Research Context and Perspective)

\begin{tabular}{|c|c|c|c|c|c|c|}
\hline & & & & & \\
\hline & & & & $\begin{array}{c}\text { No. } \\
\text { Papers }\end{array}$ & $\begin{array}{c}\% \\
\text { Total } \\
\text { No. } \\
\text { Papers }\end{array}$ & (Sample) Papers \\
\hline \multirow{9}{*}{$\begin{array}{l}\text { Research } \\
\text { Method }\end{array}$} & \multicolumn{3}{|c|}{ Theoretical } & 30 & $19 \%$ & $\begin{array}{l}\text { Amaeshi et al. (2008), Bai \& } \\
\text { Sarkis (2010), Vurro et al. } \\
\text { (2009), Jimenez \& Tachizawa }\end{array}$ \\
\hline & \multirow{8}{*}{ Empirical } & \multirow{7}{*}{$\begin{array}{l}\text { Primary } \\
\text { data }\end{array}$} & Case study & 58 & $37 \%$ & $\begin{array}{l}\text { Andersen \& Skjoett-Larsen } \\
\text { (2009), Carter \& Jennings } \\
\text { (2002), Graafland (2002), Lim \& } \\
\text { Phillips (2008), Pagell \& Wu } \\
\text { (2009), Ciliberti et al. (2009), } \\
\text { Svensson (2009) }\end{array}$ \\
\hline & & & Survey & 37 & $24 \%$ & $\begin{array}{l}\text { Ageron et al. (2011), Baden et } \\
\text { al. (2011), Beske et al. (2008), } \\
\text { Carter (2004), Holt (2004), } \\
\text { Tencati et al. (2008), Schneider } \\
\text { \& Wallenburg (2012) }\end{array}$ \\
\hline & & & $\begin{array}{l}\text { Action } \\
\text { research }\end{array}$ & 2 & $1 \%$ & $\begin{array}{l}\text { Koplin et al. (2007), Luken \& } \\
\text { Stares (2005) }\end{array}$ \\
\hline & & & $\begin{array}{l}\text { Grounded } \\
\text { Theory }\end{array}$ & 2 & $1 \%$ & $\begin{array}{l}\text { Lozano \& Huisingh (2011), Wu } \\
\text { \& Pagell (2011) }\end{array}$ \\
\hline & & & Delphi study & 1 & $0.6 \%$ & Seuring \& Muller (2008b) \\
\hline & & & $\begin{array}{l}\text { Ethnographic } \\
\text { study }\end{array}$ & 1 & $0.6 \%$ & Fassin (2008) \\
\hline & & & Mixed Method & 6 & $4 \%$ & Lee \& Kim (2009); Tsoi, (2010) \\
\hline & & \multicolumn{2}{|c|}{ Secondary data } & 26 & $17 \%$ & $\begin{array}{l}\text { Becker et al. (2010), Krueger } \\
\text { (2008), Leire \& Mont (2010), } \\
\text { Roberts (2003), Strand (2009) }\end{array}$ \\
\hline \multicolumn{4}{|c|}{ Use of Theory } & 24 & $15 \%$ & $\begin{array}{l}\text { Walker \& Jones (2012), Boyd et } \\
\text { al. (2007), Carter \& Rogers } \\
\text { (2008), Lui et al. (2011) }\end{array}$ \\
\hline \multirow{3}{*}{$\begin{array}{l}\text { Research } \\
\text { Context - } \\
\text { Contributions } \\
\text { based on } \\
\text { Primary Data }\end{array}$} & \multicolumn{3}{|c|}{ Developed countries only } & 76 & $48 \%$ & $\begin{array}{l}\text { Baden et al. (2011); Holt } \\
\text { (2004); Leire \& Mont (2010); } \\
\text { Pullman \& Dillard (2010); Wu \& } \\
\text { Pagell (2011); Eltantawy et al. } \\
\text { (2009); Svensson \& Wagner } \\
\text { (2012) }\end{array}$ \\
\hline & \multicolumn{3}{|c|}{ Developing countries only } & 21 & $13 \%$ & $\begin{array}{l}\text { Cooper et al. (2000);; Jiang } \\
\text { (2009); Kortelainen (2008); Hall } \\
\text { \& Matos (2010) }\end{array}$ \\
\hline & \multicolumn{3}{|c|}{ Developed and developing countries } & 10 & $6 \%$ & $\begin{array}{l}\text { Lozano \& Huisingh (2011); } \\
\text { Robinson (2010); MacCarthy \& } \\
\text { Jayarathne (2012) }\end{array}$ \\
\hline \multirow{3}{*}{$\begin{array}{l}\text { Research } \\
\text { Perspective - } \\
\text { Contributions } \\
\text { based on } \\
\text { Primary Data }\end{array}$} & \multicolumn{3}{|c|}{$\begin{array}{l}\text { Buyer's perspective } \\
\text { (either explicit or implicit) }\end{array}$} & 78 & $50 \%$ & $\begin{array}{l}\text { Ciliberti et al. (2009), Walker \& } \\
\text { Brammer (2009), Walker \& } \\
\text { Jones (2012), Erridge \& } \\
\text { Hennigan (2012), Preuss } \\
\text { (2009), Kolk (2012), Hollos et } \\
\text { al. (2012), Pedersen (2009), } \\
\text { Lee \& Kim (2009), Wild \& Zhou } \\
\text { (2011) }\end{array}$ \\
\hline & \multicolumn{3}{|c|}{ Supplier's perspective } & 17 & $11 \%$ & $\begin{array}{l}\text { Baden et al. (2011); Jiang } \\
\text { (2009); Lim \& Phillips (2008); } \\
\text { Luken \& Stares (2005); }\end{array}$ \\
\hline & \multicolumn{3}{|c|}{ Multi-stakeholder's perspective } & 12 & $8 \%$ & $\begin{array}{l}\text { Klassen \& Vereecke (2012); } \\
\text { Mamic (2005); Tsoi (2010) }\end{array}$ \\
\hline
\end{tabular}


Table IV - Classification of Reviewed Papers by Industry

\begin{tabular}{|c|c|c|c|c|c|c|}
\hline \multirow[b]{2}{*}{$\begin{array}{l}\text { Type of } \\
\text { Industry }\end{array}$} & \multirow[b]{2}{*}{ Frequency } & \multicolumn{3}{|c|}{ Research Context (Frequency) } & \multicolumn{2}{|c|}{ Research Design (\%) } \\
\hline & & Developed & Developing & $\begin{array}{c}\text { Cross- } \\
\text { National }\end{array}$ & $\begin{array}{c}\text { Single } \\
\text { Industry }\end{array}$ & $\begin{array}{l}\text { Multiple } \\
\text { Industry }\end{array}$ \\
\hline Apparel & 20 & 11 & 5 & 4 & $45.0 \%$ & $55.0 \%$ \\
\hline Food & 20 & 15 & 1 & 4 & $50.0 \%$ & $50.0 \%$ \\
\hline Electronics & 10 & 7 & 2 & 1 & $20.0 \%$ & $80.0 \%$ \\
\hline Footwear & 8 & 3 & 3 & 2 & $37.5 \%$ & $62.5 \%$ \\
\hline Public Sector & 7 & 4 & 1 & 2 & $85.7 \%$ & $14.3 \%$ \\
\hline $\begin{array}{c}\text { Construction } \\
\text { (materials) }\end{array}$ & 7 & 7 & 0 & 0 & $14.3 \%$ & $85.7 \%$ \\
\hline Health-care & 6 & 6 & 0 & 0 & $66.7 \%$ & $33.3 \%$ \\
\hline Machinery & 5 & 4 & 1 & 0 & $0.0 \%$ & $100.0 \%$ \\
\hline Automotive & 4 & 2 & 0 & 2 & $50.0 \%$ & $50.0 \%$ \\
\hline Chemical & 4 & 4 & 0 & 0 & $25.0 \%$ & $75.0 \%$ \\
\hline $\begin{array}{c}\text { Consultancy/ } \\
\text { IT services }\end{array}$ & 4 & 4 & 0 & 0 & $0.0 \%$ & $100.0 \%$ \\
\hline $\begin{array}{l}\text { Consumer } \\
\text { Products }\end{array}$ & 4 & 3 & 0 & 1 & $25.0 \%$ & $75.0 \%$ \\
\hline Retail & 3 & 2 & 0 & 1 & $0.0 \%$ & $100.0 \%$ \\
\hline Pharmaceutical & 2 & 2 & 0 & 0 & $0.0 \%$ & $100.0 \%$ \\
\hline $\begin{array}{c}\text { Other } \\
\text { Manufacturing }\end{array}$ & 8 & 3 & 3 & 2 & $37.5 \%$ & $62.5 \%$ \\
\hline Other Services & 6 & 5 & 0 & 1 & $83.3 \%$ & $16.7 \%$ \\
\hline $\begin{array}{c}\text { Total Frequency } \\
(\%)\end{array}$ & $\begin{array}{c}118 \\
(100 \%)\end{array}$ & $\begin{array}{c}82 \\
(69.5 \%)\end{array}$ & $\begin{array}{c}16 \\
(13.6 \%)\end{array}$ & $\begin{array}{c}20 \\
(16.9 \%)\end{array}$ & $\begin{array}{c}47 \\
(39.8 \%)\end{array}$ & $\begin{array}{c}71 \\
(60.2 \%)\end{array}$ \\
\hline
\end{tabular}


Table V - Classification of Reviewed Papers

\begin{tabular}{|c|c|c|}
\hline Area of Classification & (Sample) Papers & $\begin{array}{c}\text { No. } \\
\text { Papers }\end{array}$ \\
\hline Strategy & $\begin{array}{l}\text { Ageron et al. (2011); Awaysheh \& Klassen (2010); Carter (2004); } \\
\text { Fukukawa \& Teramoto (2009); Harwood \& Humby (2008); Jiang (2009); } \\
\text { Klassen \& Vereecke (2012); Krause et al. (2009); Maloni \& Brown (2006); } \\
\text { Pagell \& Wu (2009); Pedersen (2009); MacCarthy \& Jayarathne (2012); } \\
\text { Becker et al. (2010); Polonsky \& Jevons (2009); Kolk (2012); Wild \& Li } \\
\text { (2011); Gopalakrishnan et al. (2012); Walker \& Brammer (2012); } \\
\text { Schneider \& Wallenburg (2012) }\end{array}$ & 74 \\
\hline Organisational Culture & $\begin{array}{l}\text { Becker et al. (2010); Brammer and Walker (2011); Harwood \& Humby } \\
\text { (2008); Pedersen (2009); Pretious and Love (2006); Preuss (2007); } \\
\text { Pullman and Dillard (2010); Svensson (2009); Tsoi (2010); Walker and } \\
\text { Jones (2012); Wu and Pagell (2011) }\end{array}$ & 33 \\
\hline Risk Management & $\begin{array}{l}\text { Carter \& Rogers (2008); Harwood \& Humby (2008); Klassen \& Vereecke } \\
\text { (2012); Koplin et al. (2007); Spekman \& Davis (2004); Tate et al. (2010); } \\
\text { Spence \& Bourlakis (2009); Teuscher et al. (2006) }\end{array}$ & 8 \\
\hline \multicolumn{3}{|l|}{ Transparency } \\
\hline - Ethical Standards & $\begin{array}{l}\text { Boyd et al. (2007); Burchielli et al. (2009); Ciliberti et al. (2009); Castka } \\
\text { and Balzarova (2008); Leire and Mont (2010); Kortelainen (2008); Meehan } \\
\text { and Bryde (2011); Mueller et al. (2009); Stigzelius and Mark-Herbert } \\
\text { (2009) }\end{array}$ & 32 \\
\hline - Codes of Conduct & $\begin{array}{l}\text { Boyd et al. (2007); Colwell et al. (2011); Graafland (2002); Jiang (2009b, } \\
\text { a); (2002b, 2002a, 2004); Leire and Mont (2010); Lim and Phillips (2008); } \\
\text { Lillywhite (2007); Mamic (2005); Sobczak (2003); Svensson (2009); } \\
\text { Meehan and Bryde (2011); Robinson (2010); Yu (2008); }\end{array}$ & 31 \\
\hline - $\quad$ Reporting & $\begin{array}{l}\text { Belal (2002); Collison et al. (2008); Ciliberti et al. (2008b); Lozano \& } \\
\text { Huisingh (2011); Tate et al. (2010), Fassin (2008); Stigzelius and Mark- } \\
\text { Herbert (2009) }\end{array}$ & 8 \\
\hline \multicolumn{3}{|l|}{ Impact on Performance } \\
\hline $\begin{array}{l}\text { Relationship } \\
\text { between Socially } \\
\text { Responsible } \\
\text { Sourcing and } \\
\text { Performance }\end{array}$ & $\begin{array}{l}\text { Carter \& Jennings (2002a); Klassen \& Vereecke (2012); Luken \& Stares } \\
\text { (2005); Wittstruck \& Teuteberg (2012); Eltantawy et al. (2009); Gimenez \& } \\
\text { Tachizawa (2012); Hollos et al. (2012); Erridge \& Hennigan (2012); Joo et } \\
\text { al. (2010); Worthington (2009); Carbone et al. (2012); Gimenez et al. } \\
\text { (2012); Zailani et al. (2012); Wang \& Sarkis (2013) }\end{array}$ & 14 \\
\hline $\begin{array}{l}\text { Social } \\
\text { Sustainability } \\
\text { Indicators }\end{array}$ & $\begin{array}{l}\text { Luken \& Stares (2005); Hutchins \& Sutherland (2008); Isaksson et al. } \\
\text { (2010); Ketola (2010); Yakovleva et al. (2012); Sarkis et al. (2010); van } \\
\text { Hoek \& Johnson (2010); Taplin et al. (2006) }\end{array}$ & 8 \\
\hline
\end{tabular}


Table VI: Theoretical Lenses Identified in the Reviewed Papers

\begin{tabular}{|c|c|c|}
\hline $\begin{array}{l}\text { Main theory/concept } \\
\text { - Assoc. (sub) theories }\end{array}$ & References & Topics covered \\
\hline Contingency theory & Walker \& Jones (2012) & Strategy \\
\hline Elaborate Likelihood Model & Park (2005) & \\
\hline Legitimacy criteria & Mueller et al. (2009) & Strategy, Transparency \\
\hline $\begin{array}{l}\mathrm{N}, \mathrm{K} \text { Theory - complexity } \\
\text { theory }\end{array}$ & Hall et al. (2012) & Strategy \\
\hline Procedural Justice & Boyd et al. (2007) & Strategy, Transparency \\
\hline $\begin{array}{l}\text { RBV (Resource Based View) } \\
\text { - Population ecology theory } \\
\text { - Resource dependence theory }\end{array}$ & $\begin{array}{l}\text { De Bakker \& Nijhof (2002), Carter (2005), } \\
\text { Carter \& Rogers (2008), Hollos et al. (2012), } \\
\text { Pagell et al. }(2010) \\
\text { Carter \& Rogers (2008) } \\
\text { Carter \& Rogers (2008), Hollos et al. (2012), } \\
\text { Weise \& Toporowski (2013) }\end{array}$ & $\begin{array}{l}\text { Strategy, Risk Management, } \\
\text { Performance, Transparancy }\end{array}$ \\
\hline $\begin{array}{l}\text { Signaling Theory \& Side-bet } \\
\text { theory }\end{array}$ & Colwell et al (2011) & Transparency \\
\hline $\begin{array}{l}\text { Stakeholder Theory } \\
\text { - Stakeholder network theory }\end{array}$ & $\begin{array}{l}\text { Belal (2002), De Bakker \& Nijhof (2002), } \\
\text { Ciliberti et al. (2008b), Pagell et al. (2010), } \\
\text { Park-Poaps \& Rees (2009), Ehrgott et al. } \\
\text { (2011), Schneider \& Wallenburg (2012). } \\
\text { Vurro et al. (2009) }\end{array}$ & Transparency, Strategy \\
\hline Structuration Theory & Pullman \& Dillard (2010) & $\begin{array}{l}\text { Strategy, Organisational } \\
\text { Culture }\end{array}$ \\
\hline $\begin{array}{l}\text { TCE (Transaction cost } \\
\text { economics) } \\
\text { - RET (Relational Exchange } \\
\text { Theory)/ Agency theory } \\
\text { - Bounded rationality } \\
\end{array}$ & $\begin{array}{l}\text { Carter \& Rogers (2008), Harwood \& Humby } \\
\text { (2008), Jiang (2009a,b), Pagell et al. (2010) } \\
\text { Jiang (2009a,b), Kudla \& Klass-Wissing } \\
\text { (2012) } \\
\text { Wu \& Pagell (2011) }\end{array}$ & $\begin{array}{l}\text { Strategy, Risk Management, } \\
\text { Transparency, Organisational } \\
\text { Culture }\end{array}$ \\
\hline
\end{tabular}


Appendix: Summary of Research Themes in all Papers Reviewed (* Contributions based on primary data)

\begin{tabular}{|c|c|c|c|c|c|c|c|c|c|c|c|c|}
\hline \multirow[t]{2}{*}{$\bar{c}$} & \multirow[t]{2}{*}{ Author(s) } & \multicolumn{2}{|c|}{ Performance } & \multirow[b]{2}{*}{ Strategy } & \multirow[b]{2}{*}{$\begin{array}{c}\text { Organisational } \\
\text { culture }\end{array}$} & \multicolumn{3}{|c|}{ Transparency } & \multirow[b]{2}{*}{$\begin{array}{c}\text { Risk } \\
\text { management }\end{array}$} & \multirow[b]{2}{*}{$\begin{array}{l}\text { Developing } \\
\text { economies }\end{array}$} & \multirow[b]{2}{*}{$\begin{array}{l}\text { Supplier's } \\
\text { perspective }\end{array}$} & \multirow[b]{2}{*}{$\begin{array}{c}\text { Multi- } \\
\text { stakeholder's } \\
\text { perspective }\end{array}$} \\
\hline & & $\begin{array}{l}\text { Relationship } \\
\text { between } \\
\text { practices and } \\
\text { performance }\end{array}$ & $\begin{array}{c}\text { Sustainability } \\
\text { measures / } \\
\text { indicators }\end{array}$ & & & $\begin{array}{c}\text { Ethical } \\
\text { standards }\end{array}$ & $\begin{array}{l}\text { Codes of } \\
\text { conduct }\end{array}$ & Reporting & & & & \\
\hline 1 & Ageron et al. (2012) * & & & $x$ & & & & & & & & \\
\hline 2 & Amaeshi et al. (2008) & & & $\mathrm{X}$ & & & & & & & & \\
\hline 3 & Andersen \& Skjoett-Larsen (2009) * & & & $x$ & & & & & & & & \\
\hline 4 & Andrews et al. (2009) * & & & $x$ & & & & & & & & \\
\hline 5 & Awaysheh \& Klassen (2010) * & & & $x$ & & $x$ & $x$ & & & & & \\
\hline 6 & Baden et al. (2009) * & & & $x$ & & & & & & & $x$ & \\
\hline 7 & Baden et al. (2011) * & & & $x$ & & & & & & & $x$ & \\
\hline 8 & Bai \& Sarkis (2010) & & & & & & & & & & & \\
\hline 9 & Becker et al. (2010) & & & $x$ & $x$ & & & & & & & \\
\hline 10 & Belal (2002) & & & & & & & $x$ & & & & \\
\hline 11 & Beske et al. (2008) * & & & $x$ & & $x$ & & & & & $\mathrm{x}$ & \\
\hline 12 & Birkin et al. (2009) * & & & $x$ & & & & & & $\mathrm{x}$ & $x$ & \\
\hline 13 & Boyd et al. (2007) & & & $\mathrm{X}$ & & & & & & & & \\
\hline 14 & Brammer \& Walker (2011) * & & & $x$ & & & & & & & & \\
\hline 15 & Burchielli et al. (2009) * & & & & $x$ & $x$ & & & & & $x$ & \\
\hline 16 & Carbone et al. (2012) & $x$ & & & & & & & & & & \\
\hline 17 & Carter \& Easton (2011) & & & $\mathrm{X}$ & & & & & & & & \\
\hline 18 & Carter \& Jennings (2002a) ${ }^{*}$ & $x$ & & $x$ & $x$ & & & & & & & \\
\hline 19 & Carter \& Jennings (2002b) * & & & & & & & & & & & \\
\hline 20 & Carter \& Jennings (2004) * & & & $x$ & $x$ & & & & & & & \\
\hline 21 & Carter \& Rogers (2008) & & & $\mathrm{x}$ & & & & & $\mathrm{x}$ & & & \\
\hline 22 & Carter (2000a) * & & & & $x$ & & & & & & & $x$ \\
\hline 23 & Carter (2000b) * & & & & $x$ & & & & & & & $x$ \\
\hline 24 & Carter $(2004)^{*}$ & & & $x$ & & & & & & & & \\
\hline 25 & Castka \& Balzarova (2008a) & & & & & $x$ & & & & & & \\
\hline 26 & Castka \& Balzarova (2008b) & & & & & $x$ & & & & & & \\
\hline 27 & Ciliberti et al. (2008a) ${ }^{*}$ & & & $x$ & & $x$ & & & & & & $x$ \\
\hline 28 & Ciliberti et al. (2008b) & & & & & $\mathrm{X}$ & & $\mathrm{X}$ & & & & \\
\hline
\end{tabular}




\begin{tabular}{|c|c|c|c|c|c|c|c|c|c|c|c|c|}
\hline 29 & Ciliberti et al. (2009) * & & & & & $x$ & & & & & & \\
\hline 30 & Collison et al. (2008) & & & & & & & $\mathrm{X}$ & & & & \\
\hline 31 & Colwell et al. (2011) * & & & & & $x$ & & & & & & \\
\hline 32 & Cooper et al. $(1997)^{*}$ & & & & $x$ & & & & & & & \\
\hline 33 & Cooper et al. $(2000)^{*}$ & & & & $\mathrm{x}$ & & & & & $x$ & & \\
\hline 34 & Crespin-Mazet \& Dontenwill (2012) * & & & & $\mathrm{x}$ & & & & & & & \\
\hline 35 & De Bakker \& Nijhof (2002) & & & & & $x$ & & & & & & \\
\hline 36 & De Brito et al. (2008) * & & & $x$ & & & & & & & & \\
\hline 37 & Eadie et al. (2011) * & & & $\mathrm{x}$ & & & & & & & & \\
\hline 38 & Ehrgott et al. (2011) * & & & & $x$ & & & & & & & \\
\hline 39 & Eltantawy et al. (2009) * & $x$ & & & $x$ & & & & & & & \\
\hline 40 & Erridge \& Hennigan (2012) * & $x$ & & & & & & & & & & \\
\hline 41 & Fassin $(2008){ }^{*}$ & & & & & $\mathrm{x}$ & & & & & & \\
\hline 42 & Font et al. (2008) ${ }^{\star}$ & & & $x$ & $x$ & & & & & & & $x$ \\
\hline 43 & Forsman-Hugg et al. (2013) * & & & $x$ & & & & & & & & \\
\hline 44 & Fukukawa \& Teramoto (2009) * & & & $\mathrm{x}$ & & & & & & & & \\
\hline 45 & Gimenez \& Tachizawa (2012) & $x$ & & $\mathrm{x}$ & & $x$ & $x$ & & & & & \\
\hline 46 & Gimenez et al. (2012) * & $x$ & & & & & & & & & & \\
\hline 47 & Goebel et al. (2012) * & & & & $x$ & & & & & & & \\
\hline 48 & Gopalakrishnan et al. (2012) * & & & $x$ & & & & & & & & \\
\hline 49 & Graafland (2002) * & & & $x$ & & & $X$ & & & $x$ & & $\mathrm{x}$ \\
\hline 50 & Gugler \& Shi (2009) & & & & & $x$ & $\mathrm{x}$ & & & & & \\
\hline 51 & Hall \& Matos (2010) * & & & & & & & & & $x$ & & \\
\hline 52 & Hall et al. (2012) ${ }^{*}$ & & & & & & & & & $x$ & & \\
\hline 53 & Harwood \& Humby (2008) * & & & $x$ & $X$ & & & & $x$ & & & \\
\hline 54 & Harwood et al. (2011) * & & & & $x$ & & & & & & & \\
\hline 55 & Hoejmose \& Adrien-Kirby (2012) & & & $x$ & $x$ & & & & & & & \\
\hline 56 & Hollos et al. (2011)* & $x$ & & & & & & & & & & \\
\hline 57 & Holt (2004) * & & & $\mathrm{x}$ & & & & & & & & \\
\hline 58 & Hutchins \& Sutherland (2008) & & $x$ & & & & & & & & & \\
\hline 59 & Illge \& Preuss (2012) * & & & & & $x$ & $x$ & & & & & \\
\hline 60 & Isaksson et al. (2010) & & $x$ & $x$ & & & & & & & & \\
\hline 61 & Jiang (2009a) * & & & $\mathrm{x}$ & & & $x$ & & & $x$ & $x$ & \\
\hline 62 & Jiang (2009b) * & & & $x$ & & & $x$ & & & $x$ & $x$ & \\
\hline
\end{tabular}




\begin{tabular}{|c|c|c|c|c|c|c|c|c|c|c|c|c|}
\hline 63 & Joo et al. (2010) & $x$ & & & & & & & & & & \\
\hline 64 & Jorgensen \& Knudsen (2006) * & & & $x$ & & & & & & & & $x$ \\
\hline 65 & Kaptein (2004) & & & & & & $x$ & & & & & \\
\hline 66 & Keating et al. (2008) * & & & $X$ & & & $x$ & & & & & \\
\hline 67 & Ketola (2010) & & $x$ & $\mathrm{x}$ & & & & & & & & \\
\hline 68 & Klassen \& Vereecke (2012) * & $\mathrm{x}$ & & $x$ & & & & & $\mathrm{x}$ & & & $\mathrm{X}$ \\
\hline 69 & Kleindorfer et al. (2005) & & & & & & & & & & & \\
\hline 70 & Kogg \& Mont (2012) * & & & $\mathrm{x}$ & $\mathrm{x}$ & & & & & & & \\
\hline 71 & Kolk \& Tulder (2002a) & & & $x$ & & & $x$ & & & & & \\
\hline 72 & Kolk \& Tulder (2002b) & & & & & & $x$ & & & & & \\
\hline 73 & Kolk \& Tulder (2004) & & & $x$ & & & $x$ & & & & & \\
\hline 74 & Kolk (2012) * & & & $x$ & & & & & & & & \\
\hline 75 & Koplin et al. (2007) * & & & $\mathrm{x}$ & & & & & $x$ & & & \\
\hline 76 & Kortelainen (2008) * & & & & & $X$ & & & & $x$ & $X$ & \\
\hline 77 & Krause et al. (2009) & & & $\mathrm{X}$ & & & & & & & & \\
\hline 78 & Krueger (2008) & & & & & $x$ & $x$ & & & & & \\
\hline 79 & Kudla \& Klaas-Wissing (2012) * & & & $x$ & $x$ & & & & & & & $\mathrm{x}$ \\
\hline 80 & Lamberti \& Lettieri (2009) * & & & $x$ & & & & & & & & \\
\hline 81 & Lee \& Kim (2009) * & & & & & $x$ & & $x$ & & $x$ & $x$ & \\
\hline 82 & Lehtinen (2012) * & & & & & & & & & & & \\
\hline 83 & Leire \& Mont (2010) * & & & & & & $x$ & & & & & \\
\hline 84 & Lillywhite $(2007){ }^{*}$ & & & & & $x$ & $x$ & & & & & $\mathrm{X}$ \\
\hline 85 & Lim \& Phillips (2008) * & & & $x$ & & & $x$ & & & $x$ & $x$ & \\
\hline 86 & Lozano \& Huisingh (2011) ${ }^{*}$ & & & & & & & $x$ & & & & \\
\hline 87 & Luken \& Stares $(2005){ }^{*}$ & $\mathrm{x}$ & $x$ & & & & & & & $\mathrm{x}$ & $x$ & \\
\hline 88 & MacCarthy \& Jayarathne (2012) * & & & $x$ & & $x$ & $x$ & & & & & $x$ \\
\hline 89 & Maignan et al. (2002) & & & $x$ & $x$ & & & & & & & \\
\hline 90 & Maloni \& Brown (2006) & & & $\mathrm{x}$ & & & & & & & & \\
\hline 91 & Mamic (2005) * & & & & & $\mathrm{x}$ & $x$ & & & & & $\mathrm{x}$ \\
\hline 92 & Manning (2013) & & & $x$ & & & & & & & & \\
\hline 93 & Manning et al. (2006) & & & & & $x$ & & & & & & \\
\hline
\end{tabular}




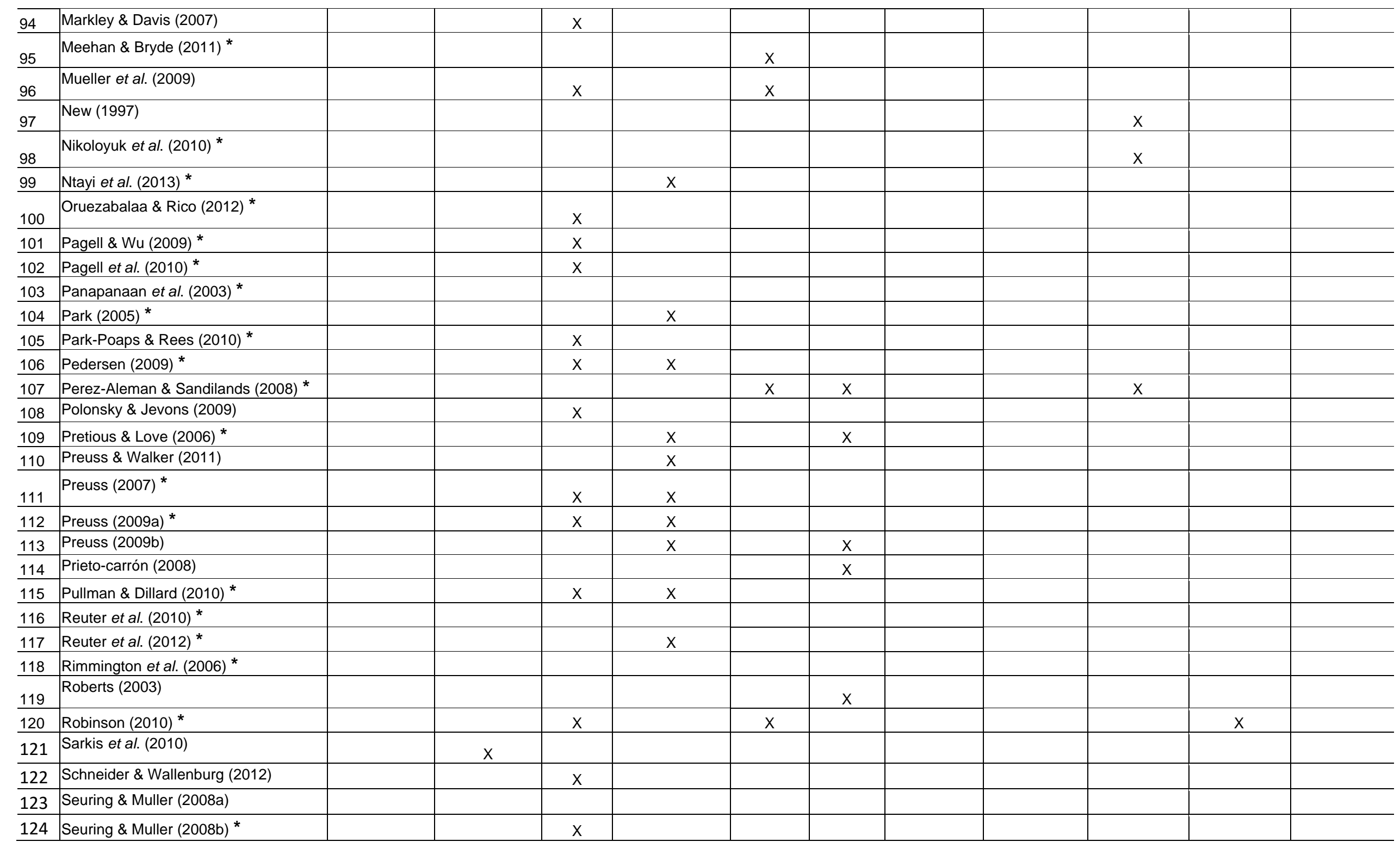




\begin{tabular}{|c|c|c|c|c|c|c|c|c|c|c|c|c|}
\hline 125 & Sobczak (2003) & & & & & & $x$ & & & & & \\
\hline 126 & Spekman \& Davis (2004) & & & & & & & & $x$ & & & \\
\hline 127 & Spence \& Bourlakis (2009) * & & & $x$ & & $x$ & $\mathrm{x}$ & & $x$ & & $\mathrm{x}$ & \\
\hline 128 & Stigzelius \& Mark-Herbert (2009) * & & & & & $x$ & & & & $x$ & $x$ & \\
\hline 129 & Strand (2009) & & & $x$ & & & & & & & & \\
\hline 130 & Svensson \& Wagner (2012) * & & & & & & & & & & & \\
\hline 131 & Svensson (2009) * & & & & $\mathrm{x}$ & $\mathrm{x}$ & & & & & & \\
\hline 132 & Taplin et al. (2006) * & & $x$ & & & & & $x$ & & & & \\
\hline 133 & Tate et al. (2010) & & & $x$ & & & & $x$ & $x$ & & & \\
\hline 134 & Tencati et al. (2008) * & & & & & & & & & $x$ & $x$ & \\
\hline 135 & Teuscher et al. (2006) & & & & & $x$ & & $x$ & $x$ & & & \\
\hline 136 & Tsoi $(2010)^{*}$ & & & & $x$ & & & & & $x$ & & $x$ \\
\hline 137 & Van Hoek \& Johnson (2010) * & & $x$ & & & & & & & & & \\
\hline 138 & Van Tulder \& Kolk (2001) & & & & & & $x$ & & & & & \\
\hline 139 & Van Tulder et al. (2009) * & & & & & & $x$ & & & & & \\
\hline 140 & Vasileiou \& Morris (2006) * & & & & & & & & & & & \\
\hline 141 & Vurro et al. (2009) & & & $x$ & & & & & & & & \\
\hline 142 & Walker \& Brammer (2009) * & & & & & & & & & & & \\
\hline 143 & Walker \& Brammer (2012) * & & & $x$ & & & & & & & & \\
\hline 144 & Walker \& Jones (2012) ${ }^{*}$ & & & $x$ & $x$ & & & & & & & \\
\hline 145 & Walker \& Preuss (2008) * & & & $x$ & & & & & & & & \\
\hline 146 & Wang \& Sarkis (2013) & $x$ & & & & & & & & & & \\
\hline 147 & Welford \& Frost (2006) * & & & $x$ & & $x$ & $\mathrm{x}$ & & & $\mathrm{x}$ & & \\
\hline 148 & Wiese \& Toporowski (2013) * & & & & & $x$ & $x$ & & & & & \\
\hline 149 & Wild \& Zhou (2011) * & & & $x$ & & & & & & & & \\
\hline 150 & Winstanley et al. (2002) * & & & $x$ & & $x$ & $x$ & & & $x$ & $x$ & \\
\hline 151 & Winter \& Knemeyer (2013) & & & & & & & & & & & \\
\hline 152 & Wittstruck \& Teuteberg (2012) * & $x$ & & $x$ & & & & & & & & \\
\hline 153 & Worthington (2009) * & $x$ & & & & & & & & & & \\
\hline 154 & Wu \& Pagell (2011) * & & & & $x$ & & & & & & & \\
\hline 155 & Yakovleva et al. (2011) * & & $X$ & & & & & & & & & \\
\hline 156 & Yu (2008)* & & & & & & $x$ & & & $x$ & $x$ & \\
\hline
\end{tabular}




\begin{tabular}{|c|c|c|c|c|c|c|c|c|c|c|c|c|}
\hline 157 & Zailani et al. (2012) * & $\mathrm{x}$ & & & & & & & & $\mathrm{x}$ & & \\
\hline & Total & 14 & 8 & 74 & 33 & 32 & 31 & 8 & 8 & 21 & 17 & 12 \\
\hline
\end{tabular}

